OPEN ACCESS

Edited by:

Steven Thomas Leach,

University of

New South Wales, Australia

Reviewed by:

Victor Manuel Navas-López,

Hospital Materno-Infantil, Spain

Uday C. Ghoshal,

Sanjay Gandhi Post Graduate Institute

of Medical Sciences, India

*Correspondence:

David Avelar Rodriguez

davidavelar1@outlook.com

Specialty section:

This article was submitted to

Pediatric Gastroenterology,

Hepatology and Nutrition,

a section of the journal

Frontiers in Pediatrics

Received: 15 May 2019

Accepted: 20 August 2019

Published: 04 September 2019

Citation:

Avelar Rodriguez D, Ryan PM, Toro

Monjaraz EM, Ramirez Mayans JA and Quigley EM (2019) Small Intestinal

Bacterial Overgrowth in Children: A

State-Of-The-Art Review.

Front. Pediatr. 7:363.

doi: 10.3389/fped.2019.00363

\section{Small Intestinal Bacterial Overgrowth in Children: A State-Of-The-Art Review}

\author{
David Avelar Rodriguez ${ }^{1 *}$, Paul MacDaragh Ryan ${ }^{2}$, Erick Manuel Toro Monjaraz", \\ Jaime Alfonso Ramirez Mayans ${ }^{1}$ and Eamonn Martin Quigley ${ }^{3}$
}

${ }^{1}$ Pediatric Gastroenterology and Nutrition Unit, National Institute of Pediatrics, Mexico City, Mexico, ${ }^{2}$ School of Medicine, University College Cork, Cork, Ireland, ${ }^{3}$ Lynda K. and David M. Underwood Center for Digestive Disorders, Houston Methodist Hospital, Houston, TX, United States

Small intestinal bacterial overgrowth $(\mathrm{SIBO})$ is a heterogenous and poorly understood entity characterised by an excessive growth of select microorganisms within the small intestine. This excessive bacterial biomass, in turn, disrupts host physiology in a myriad of ways, leading to gastrointestinal and non-gastrointestinal symptoms and complications. SIBO is a common cause of non-specific gastrointestinal symptoms in children, such as chronic abdominal pain, abdominal distention, diarrhoea, and flatulence, amongst others. In addition, it has recently been implicated in the pathophysiology of stunting, a disease that affects millions of children worldwide. Risk factors such as acid-suppressive therapies, alterations in gastrointestinal motility and anatomy, as well as impoverished conditions, have been shown to predispose children to SIBO. SIBO can be diagnosed via culture-dependant or culture-independent approaches. SIBO's epidemiology is limited due to the lack of uniformity and consensus of its diagnostic criteria, as well as the paucity of literature available. Antibiotics remain the first-line treatment option for SIBO, although emerging modalities such as probiotics and diet manipulation could also have a role. Herein, we present a state-of-the-art-review which aims to comprehensively outline the most current information on SIBO in children, with particular emphasis on the gut microbiota.

\footnotetext{
Keywords: small intestine bacterial overgrowth, small intestinal bacterial overgrowth, small bowel bacterial overgrowth, proton pump inhibitors, gut microbiota, stunting
}

\section{INTRODUCTION}

Small intestinal bacterial overgrowth (SIBO) is a heterogenous disorder characterised by an excessive growth of select microorganisms within the small intestine. This excessive bacterial biomass, in turn, disrupts host physiology in a myriad of ways, leading to gastrointestinal and non-gastrointestinal symptoms and complications (1). SIBO is a common cause of non-specific gastrointestinal symptoms in children, such as chronic abdominal pain, abdominal distention, diarrhoea, and flatulence, amongst others (2-5). In addition, it has recently been implicated in the pathophysiology of stunting (6), a disease that affects millions of children worldwide. Certain risk factors, such as acid-suppressive therapies (7-10), alterations in gastrointestinal motility and anatomy (11-20), and impoverished conditions (21-26), have been shown to predispose children to SIBO. Despite the relatively high prevalence of SIBO in children, it remains a poorly understood 
disorder. In fact, only a small number of studies have been published in the last two decades. Since the year 2000, only 149 articles have been published on paediatric SIBO (Figure 1). Due to this previous scarcity of literature and the recent emergence of novel, informative data regarding the underpinnings of the disease, an update for practicing paediatricians is now warranted. This article represents a state-of-the-art review which aims to comprehensively outline the most current information on SIBO in children, with particular emphasis on the gut microbiota.

\section{SEARCH STRATEGY AND SELECTION CRITERIA}

In December 2018, two investigators systematically searched the PubMed/MEDLINE, EBSCOhost, Google Scholar, and ResearchGate databases using the primary search blocks "small intestine bacterial overgrowth OR small intestinal bacterial overgrowth OR small bowel bacterial overgrowth AND children" and "small intestine bacterial overgrowth OR small intestinal bacterial overgrowth OR small bowel bacterial overgrowth." In addition, the following terms were used in combination: "small intestinal bacterial overgrowth," "pathophysiology," "16S rRNA sequencing," "next generation sequencing," "gut microbiota," "proton pump inhibitors," "juvenile systemic

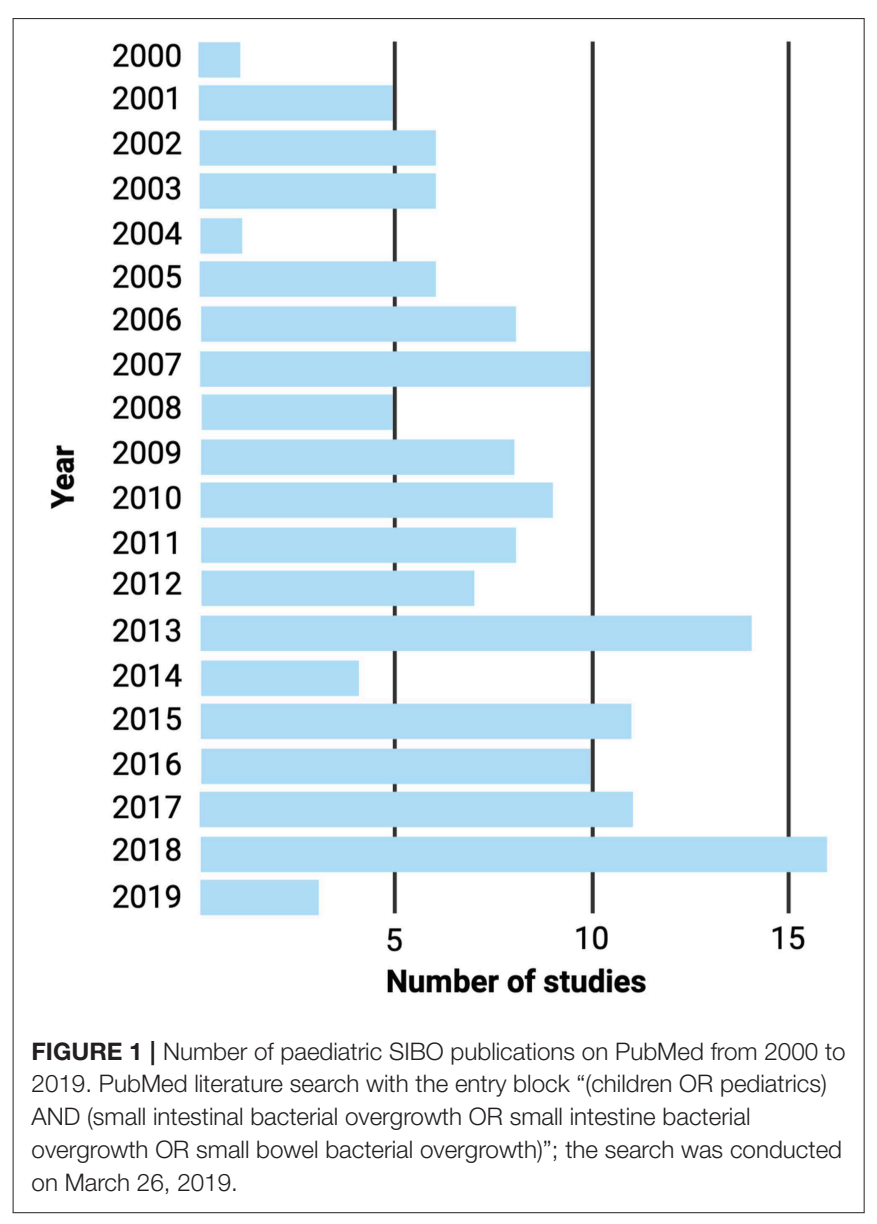

sclerosis," "scleroderma," "ileocecal valve," "vitamin," "functional gastrointestinal disorders," "chronic abdominal pain," "irritable bowel syndrome," "constipation," "hydrogen," "methane," "breath test," "stunted," "environmental enteric dysfunction," "environmental enteropathy," "Methanobrevibacter smithii," "methanogens," "immunodeficiency," and "coeliac disease." The search was restricted to titles and abstracts written in English and Spanish, and no date range restriction was applied. We also searched for ongoing clinical trials in Clinicaltrials.gov with the term "small intestinal bacterial overgrowth." Adult patient studies were included when relevant. In addition, we screened the reference lists of the selected papers and created weekly alerts on PubMed to enhance the sensitivity of the search. The last literature search was conducted on May 13th, 2019.

\section{THE GASTROINTESTINAL TRACT AND THE GUT MICROBIOTA}

Each of the organs and anatomical portions of the gastrointestinal system provides specific functions and are equipped with mechanisms to promote a homeostatic relationship with its indigenous bacterial community (microbiota) $(27,28)$. This mutualistic homeostasis is achieved through mechanisms including gastric and bile acids, pancreatic and digestive secretions, intestinal motility, the barrier function of the ileocecal valve, amongst others. Within the lumen of the gastrointestinal tract resides the gut microbiota, a complex and susceptible microbial consortium composed of entericadapted bacteria, which is acquired in the very early stages of life and develops in concert with the host. The "sterile womb hypothesis" refers to the notion that the neonate acquires the gut microbiota during birth through ingestion of the mother's vaginal (vaginal delivery) or skin (caesarean section) microbiota. In contrast, although increasing evidence has suggested that the infant gut microbiota is acquired in utero, a technically comprehensive multimodal investigation recently failed to detect any placenta dwelling microorganisms (29). The gut microbiota maintains a life-long symbiotic relationship with the human host, providing a plethora of important functions; from vitamin and short-chain fatty acid (SCFA) production to immunoregulation and neuropeptide secretion [for review see (30)].

The composition and functionality of the gut microbiota is shaped and influenced by a multitude of intrinsic and extrinsic factors, such as genetics, mode of delivery, gestational age, feeding type and diet, pharmaceuticals, and exercise (30). The composition of the gut microbiota exhibits variations related to the anatomical portion studied, which is mainly influenced by factors such as the luminal oxygen concentration and $\mathrm{pH}$. Indeed, bacterial numbers increase from about $10^{3}$ to $10^{4} / \mathrm{ml}$ in the stomach to approximately $10^{11} / \mathrm{ml}$ in the colon (Figure 2) (31-33). The colonic microbiota is the largest prokaryotic community in the human body, representing nearly the $0.3 \%$ of the overall host body weight (34). Although composed largely of four bacterial phyla Actinobacteria, Firmicutes, Bacteroidetes, and Proteobacteria- 


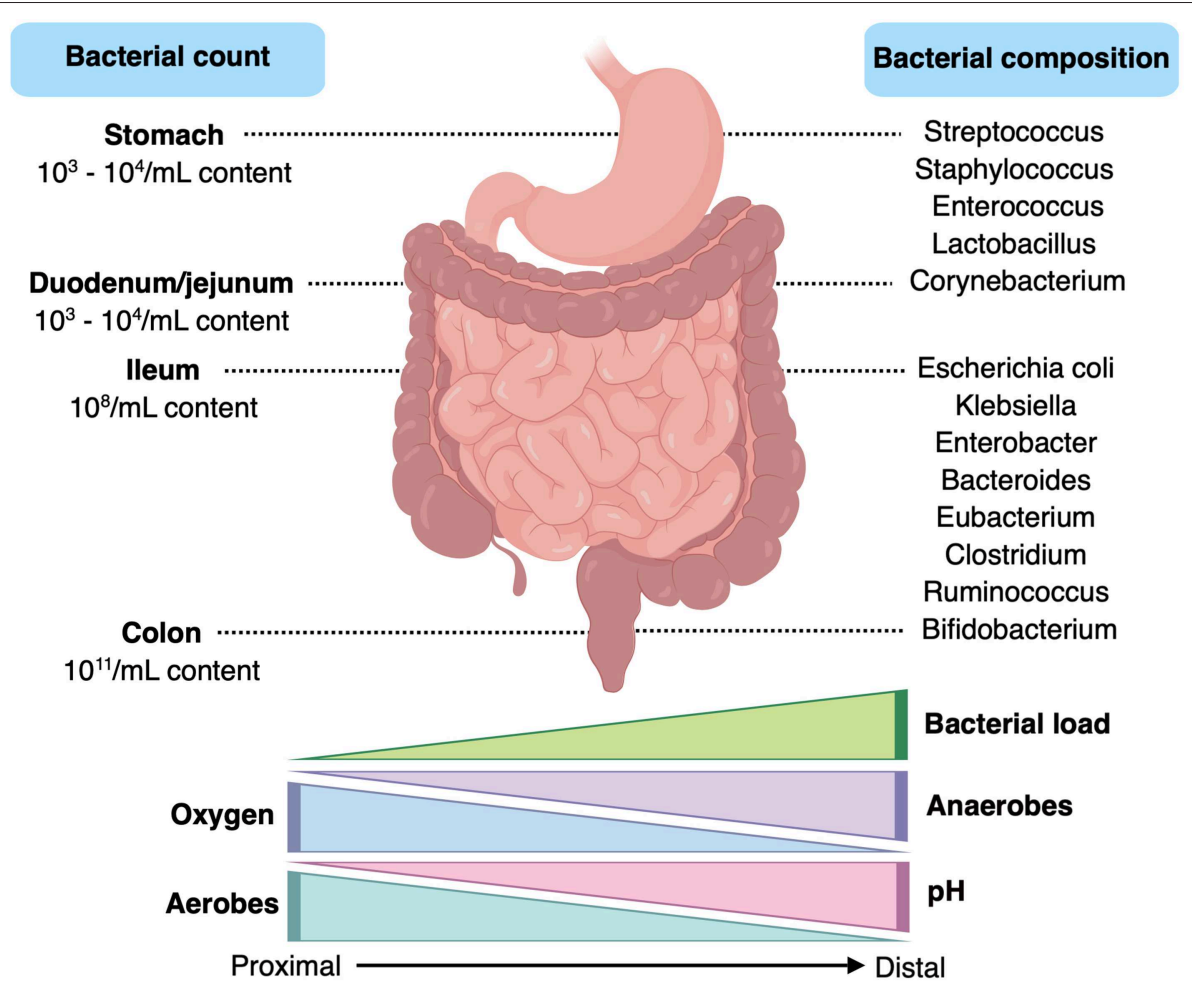

FIGURE 2 | Gastrointestinal tract features and bacterial composition and content. Created with BioRender.com.

the infantile gut microbiome is dominated by Actinobacteria, with Firmicutes emerging to dominate after infancy (35). In general, bacteria from the Actinobacteria (e.g., Bifidobacterium), Firmicutes (e.g., Faecalibacterium, Clostridium, Ruminococcus, Lactobacillus) and Bacteroidetes (e.g., Bacteroides, Prevotella) phyla are largely regarded as commensal microorganisms, while a significant portion of gastrointestinal pathogens belong to the Proteobacteria phylum (e.g., Escherichia, Shigella, Salmonella, Klebsiella, and Helicobacter, amongst others) (36, 37). In addition to this diverse community of bacteria, the human gastrointestinal tract is also home to an extensive array of viruses (38), fungi (39), and archaea (40). While it remains unclear at present as to whether the former two kingdoms play a significant role in SIBO pathogenesis, methanogenic archaea, such as Methanobrevibacter spp., have been directly implicated in a methane-specific form of the disorder (41).

It is important to note, however, that despite the substantial advances made in the study of the gut microbiota in general, the small bowel microbiota remains poorly understood (42). Whereas the colonic microbiota is more easily accessible and can be sampled via colonoscopy or faecal sample (43), sampling of the small bowel microbiota poses a major challenge due to the invasiveness of the procedures (upper endoscopy) and the technical difficulties associated with these. Therefore, this significantly obscures our understanding of SIBO and hampers the establishment of a definition.

\section{THE EPIDEMIOLOGY OF SIBO IN CHILDREN}

The prevalence of SIBO in children has been explored in a wide spectrum of clinical contexts, including children living in impoverished conditions, individuals with chronic abdominal pain (CAP), as well as those who suffer from irritable bowel syndrome (IBS), stunting, and obesity, amongst other diseases. SIBO prevalence ranges from about $9 \%$ in children taking proton pump inhibitors (PPIs) (7) to approximately $90 \%$ in those with stunted growth (6) and chronic abdominal pain (CAP) (2). However, it should be noted that the data on the epidemiology of SIBO in children is limited by the small number of studies available, the lack of appropriate controls in some studies, and the varying test methodology and diagnostic cut-offs applied. Table 1 shows the study characteristics and reported SIBO prevalence in children with a wide variety of clinical contexts and risk factors.

\section{SIBO PATHOGENESIS}

SIBO can negatively impact the host in a range of ways $(1,31,53-$ 61). These include bacterial carbohydrate fermentation leading to excess gas and water production (1); bacterial deconjugation of bile acids resulting in poorly absorbed liposoluble vitamins (18); bacterial macronutrient and micronutrient consumption (bacterial-host nutrient competition), leaving the host with less available nutrients for absorption (58); villous blunting leading to carbohydrate malabsorption $(13,62-64)$; decreased short 
TABLE 1 | Study characteristics and reported SIBO prevalence in children with a wide variety of clinical contexts and risk factors.

\begin{tabular}{|c|c|c|c|c|c|c|}
\hline References & Year & Study population & Study design & $\begin{array}{l}\text { Sample size } \\
\text { (n) }\end{array}$ & $\begin{array}{l}\text { Diagnostic tests and criteria for } \\
\text { positivity }\end{array}$ & $\begin{array}{l}\text { Reported SIBO } \\
\text { prevalence* }\end{array}$ \\
\hline Pignata et al. (44) & 1990 & $\begin{array}{l}\text { Children with immunodeficiency } \\
\text { syndromes aged } 2 \text { to } 17 \text { years } \\
\text { and age-matched control } \\
\text { children. }\end{array}$ & Cross-sectional & $\begin{array}{l}\text { Cases: } 17 \\
\text { Controls: } 10\end{array}$ & $\begin{array}{l}\text { Jejunal aspirate cultures (not } \\
\text { performed in controls due to ethical } \\
\text { reasons). Positivity was defined as } \\
\geq 10^{5} \mathrm{CFU} / \mathrm{ml} \text {. } \\
\text { GHBT } \\
\text { Cut-off point was defined as } 10 \mathrm{ppm} \text {. }\end{array}$ & $\begin{array}{l}\text { Jejunal aspirate: } \\
\text { Cases: } 41 \%\end{array}$ \\
\hline Lewindon et al. (13) & 1998 & $\begin{array}{l}\text { Children with cystic fibrosis and } \\
\text { non-cystic fibrosis children } \\
\text { (controls). }\end{array}$ & Cross-sectional & $\begin{array}{l}\text { Cases: } 19 \\
\text { Controls: } 508\end{array}$ & $\begin{array}{l}\text { LHBT } \\
\text { Positivity was not specified. }\end{array}$ & $\begin{array}{l}\text { Cases: } 32 \% \\
\text { Controls: } 7 \% \\
P:<0.003\end{array}$ \\
\hline $\begin{array}{l}\text { Fontanele Soares et al. } \\
\text { (20) }\end{array}$ & 2005 & $\begin{array}{l}\text { Children with chronic } \\
\text { constipation aged } 3 \text { to } 13 \text { years. }\end{array}$ & Cross-sectional & Cases: 40 & $\begin{array}{l}\mathrm{CH}_{4} \text { breath test } \\
\text { Positivity (methane producers) was } \\
\text { defined as a methane concentration } \\
<3 \text { ppm. }\end{array}$ & $73.5 \%$ \\
\hline Dos Reis et al. (22) & 2007 & $\begin{array}{l}\text { Children living in a slum and age } \\
\text { and sex-matched controls aged } \\
5 \text { to } 11 \text { years. }\end{array}$ & Cross-sectional & $\begin{array}{l}\text { Cases: } 50 \\
\text { Controls: } 50\end{array}$ & $\begin{array}{l}\text { Glucose and lactulose } \mathrm{H}_{2} \text { breath } \\
\text { tests. } \\
\text { Positivity was defined as an increase } \\
\text { in } \mathrm{H}_{2} \text { of } \geq 20 \text { ppm over baseline in the } \\
\text { initial } 60 \text { min. }\end{array}$ & $\begin{array}{l}\text { Lactulose: } \\
\text { Cases: } 37.5 \% \\
\text { Controls: } 2.1 \% \\
P:<0.001\end{array}$ \\
\hline Scarpellini et al. (45) & 2009 & $\begin{array}{l}\text { Children with IBS (Rome II } \\
\text { criteria) and healthy age- and } \\
\text { sex-matched controls. }\end{array}$ & Cross-sectional & $\begin{array}{l}\text { Cases: } 43 \\
\text { Controls: } 56\end{array}$ & $\begin{array}{l}\text { Lactulose } \mathrm{H}_{2} / \mathrm{CH}_{4} \text { breath test. } \\
\text { Positivity was defined as an early rise } \\
\text { in } \mathrm{H}_{2} \text { or } \mathrm{CH}_{4} \text { excretion of }>20 \text { ppm } \\
\text { within the first } 90 \text { min. }\end{array}$ & $\begin{array}{l}\text { Cases: } 65 \% \\
\text { Controls: } 7 \% \\
P:<0.00001\end{array}$ \\
\hline Lisowska et al. (11) & 2009 & $\begin{array}{l}\text { Children with cystic fibrosis and } \\
\text { controls with gastrointestinal } \\
\text { symptoms aged } 5 \text { to } 17 \text { years. }\end{array}$ & Cross-sectional & $\begin{array}{l}\text { Cases: } 62 \\
\text { Controls: } 390\end{array}$ & $\begin{array}{l}\text { Glucose } \mathrm{H}_{2} / \mathrm{CH}_{4} \text { breath test. } \\
\text { Positivity was defined as a fasting } \mathrm{H}_{2} \\
\text { or } \mathrm{CH} 4 \text { level of } \geq 20 \mathrm{ppm} \text { and } \geq 10 \\
\text { ppm, respectively; or an increase in } \\
\mathrm{H}_{2} \text { or } \mathrm{CH} 4 \text { over baseline during the } \\
\text { test of } \geq 12 \mathrm{pm} \text { and } \geq 6 \text {, respectively. }\end{array}$ & $\begin{array}{l}\text { Cases: } 37.1 \% \\
\text { Controls: } 13.3 \% \\
P:<0.00001\end{array}$ \\
\hline Collins et al. (46) & 2010 & $\begin{array}{l}\text { Children with CAP (Rome II } \\
\text { criteria) aged } 8 \text { to } 18 \text { years and } \\
\text { healthy controls. }\end{array}$ & Cross-sectional & $\begin{array}{l}\text { Cases: } 75 \\
\text { Controls: } 40\end{array}$ & $\begin{array}{l}\text { LHBT. } \\
\text { Positivity was defined as a rise in } \mathrm{H}_{2} \\
>20 \text { ppm before the first } 90 \mathrm{~min}\end{array}$ & $\begin{array}{l}\text { Cases: } 91 \% \\
\text { Controls: } 35 \% \\
P:<0.0001\end{array}$ \\
\hline Cole et al. (16) & 2010 & $\begin{array}{l}\text { Children younger than } 2 \text { years } \\
\text { with short bowel syndrome } \\
\text { receiving enteral feeds }\end{array}$ & Prospective & Cases: 10 & $\begin{array}{l}\text { GHBT } \\
\text { Positivity was defined as either an } \\
\text { increased fasting breath } \mathrm{H}_{2} \geq 20 \\
\text { ppm or increase from baseline of } \geq 10 \\
\text { ppm after glucose ingestion }\end{array}$ & $\begin{array}{l}\text { (incidence) } \\
50 \%\end{array}$ \\
\hline
\end{tabular}


TABLE 1 | Continued

\begin{tabular}{|c|c|c|}
\hline References & Year & Study population \\
\hline Leiby et al. (15) & 2010 & $\begin{array}{l}\text { Children with secondary retentive } \\
\text { faecal incontinence (and } \\
\text { radiographically diagnosed } \\
\text { faecal impaction) aged } 6 \text { to } 12 \\
\text { years and controls with } \\
\text { gastrointestinal symptoms but } \\
\text { without faecal incontience. }\end{array}$ \\
\hline Jones et al. (47) & 2011 & $\begin{array}{l}\text { Children with chronic diarrhoea } \\
\text { and/or abdominal pain and/or } \\
\text { bloating and/or irritability younger } \\
\text { than } 15 \text { years of age. }\end{array}$ \\
\hline Mello et al. (23) & 2012 & $\begin{array}{l}\text { Children of poor socioeconomic } \\
\text { conditions residing in a slum and } \\
\text { children of socioeconomically } \\
\text { advantaged families aged } 6 \text { to } \\
10 \text { years. }\end{array}$ \\
\hline
\end{tabular}

Gutierrez et al. (17)

Scarpellini et al. (48)

Ojetti et al. (14)

Hegar et al. (9)
2012 Children with intestinal failure and refractory gastrointestinal symptoms (i.e., abdominal bloating, emesis, diarrhoea, or increased stoma output) with a median age of 5 years.

2013 Children with IBS (Rome II criteria).

Study objective: to assess the effects of rifaximin treatment on $\mathrm{SIBO}$

prevalence and gastrointestinal symptoms in children affected by IBS.

2013 Children with myelomeningocele and constipation.

2013 Children with epigastric pain and a normal baseline GHBT aged $\geq 5$ years were divided into two 4-week trial groups: group 1 (cases): omeprazole plus Lacidofil ${ }^{\circledR}(1.9 \times 109 \mathrm{CFU}$ Lactobacillus rhamnosus R0011 and $0.1 \times 109 \mathrm{CFU}$

Lactobacillus acidophillus R0052); and group 2 (controls): omeprazole plus placebo capsule.

Study objective: to evaluate the incidence of SIBO in children treated with omeprazole and to test whether probiotics influence the incidence.
Cross-sectional Cases: 287

Cross-sectional

Cases: 85

Controls: 43

Cross-sectional

Cases: 57

$\mathrm{CH}_{4}$-producers when the

concentration of $\mathrm{CH}_{4}$ was $\geq 3$.

Duodenal aspirate cultures. Positivity was defined as a bacterial growth of $\geq 10^{5} \mathrm{CFU} / \mathrm{ml}$.

Prospective

Cases: 50

Lactulose $\mathrm{H}_{2} / \mathrm{CH}_{4}$ breath test. Positivity was defined as an early rise in $\mathrm{H}_{2}$ or $\mathrm{CH}_{4}$ excretion $>20 \mathrm{ppm}$ within the first $90 \mathrm{~min}$.
Cross-sectional

Double-blinded, randomized clinical trial
Cases: 18

Cases: 36 Controls: 34

Contr: 34

Lactulose $\mathrm{H}_{2} / \mathrm{CH}_{4}$ breath test. Positivity was not specified.

GHBT.

Positive test was defined as an increase in $\mathrm{H}_{2}$ of $>10 \mathrm{ppm}$ over baseline.
Reported SIBO

prevalence*

Cases: $42 \%$

Controls: $23 \%$ increase in $\mathrm{H}_{2} \geq 20 \mathrm{ppm}$ or in $\mathrm{CH}_{4}$ Patients were considered $\mathrm{CH}_{4}$ producers if their level was more than baseline sample was > 10 ppm.

$87 \%$

Cases: $30.9 \%$

Controls: $2.4 \%$

P: 0.0007

$70 \%$

$66 \%$

$39 \%$

(incidence)

Cases: $33 \%$

Controls: $26 \%$

P: 0.13 
TABLE 1 | Continued

\begin{tabular}{|c|c|c|c|c|c|c|}
\hline References & Year & Study population & Study design & $\begin{array}{l}\text { Sample size } \\
\text { (n) }\end{array}$ & $\begin{array}{l}\text { Diagnostic tests and criteria for } \\
\text { positivity }\end{array}$ & $\begin{array}{l}\text { Reported SIBO } \\
\text { prevalence* }\end{array}$ \\
\hline Rosen et al. (8) & 2014 & $\begin{array}{l}\text { Children taking acid suppressive } \\
\text { therapy for a minimum of } 4 \\
\text { weeks (PPIs and histamine-2 } \\
\text { antagonists) and controls (no } \\
\text { acid suppressive therapy) aged } 1 \\
\text { to } 18 \text { years }\end{array}$ & Cross-sectional & $\begin{array}{l}\text { Cases: } 48 \\
\text { Controls: } 51\end{array}$ & $\begin{array}{l}\text { Gastric aspirate cultures. } \\
\text { Positivity was not clearly specified. }\end{array}$ & $\begin{array}{l}\text { Cases: } 46 \% \\
\text { Controls: } 18 \% \\
\text { P: } 0.003\end{array}$ \\
\hline Lisowska et al. (49) & 2014 & $\begin{array}{l}\text { Children with progressive familial } \\
\text { intrahepatic cholestasis aged } 8 \\
\text { to } 25 \text { years. }\end{array}$ & Prospective & Cases: 26 & $\begin{array}{l}\text { Glucose } \mathrm{H}_{2} / \mathrm{CH}_{4} \text { breath test. } \\
\text { Positivity was defined as a high } \\
\text { baseline value ( }>20 \mathrm{ppm} \text { for } \\
\text { hydrogen or }>10 \mathrm{ppm} \text { for methane) } \\
\text { or an early increase of gas excretion } \\
\text { (>12 ppm for hydrogen or }>6 \mathrm{ppm} \\
\text { for methane). }\end{array}$ & $35 \%$ \\
\hline Sieczkowska et al. (10) & 2015 & $\begin{array}{l}\text { Children with histology-proven } \\
\text { peptic esophagitis aged } 3 \text { to } 18 \\
\text { years. } \\
\text { Study objective: to evaluate } \\
\text { whether a 3-month PPI } \\
\text { treatment regimen induces } \\
\text { SBBO in children and if so, to } \\
\text { determine } \\
\text { associated symptoms. }\end{array}$ & Prospective & Cases: 40 & $\begin{array}{l}\text { Glucose } \mathrm{H}_{2} / \mathrm{CH}_{4} \text { breath test. } \\
\text { Positivity was defined as an increase } \\
\text { in } \mathrm{H}_{2} \text { of } \geq 10 \text { over baseline. }\end{array}$ & $22.5 \%$ \\
\hline Donowitz et al. (25) & 2016 & $\begin{array}{l}\text { Bangladeshi children from an } \\
\text { impoverished neighbourhood } \\
\text { aged } 2 \text { years. }\end{array}$ & Cross-sectional & Cases: 90 & $\begin{array}{l}\text { GHBT. } \\
\text { Positivity was defined as an increase } \\
\text { in } \mathrm{H}_{2} \text { of } \geq 12 \mathrm{ppm} \text { over baseline. }\end{array}$ & $16.7 \%$ \\
\hline Wang et al. (50) & 2017 & $\begin{array}{l}\text { Children with autism spectrum } \\
\text { disorder and age- and } \\
\text { sex-matched healthy controls } \\
\text { (age was not specified) }\end{array}$ & Cross-sectional & $\begin{array}{l}\text { Cases: } 310 \\
\text { Controls: } 1240\end{array}$ & $\begin{array}{l}\text { Glucose } \mathrm{H}_{2} / \mathrm{CH}_{4} \text { breath test. } \\
\text { Positivity was defined as an increase } \\
\text { in } \mathrm{H}_{2} \text { of } \geq 20 \mathrm{ppm} \text { or } \mathrm{CH}_{4} \text { of } \geq 10 \\
\text { ppm over baseline before the } \\
\text { first } 60 \text { min. }\end{array}$ & $\begin{array}{l}\text { Cases: } 31.0 \% \\
\text { Controls: } 9.3 \% \\
P:<0.0001\end{array}$ \\
\hline Mello et al. (24) & 2017 & $\begin{array}{l}\text { Children of low socio-economic } \\
\text { status living in an urban slum } \\
\text { aged } 5 \text { to } 11 \text { years }\end{array}$ & Cross-sectional & Cases: 100 & $\begin{array}{l}\text { Lactulose } \mathrm{H}_{2} / \mathrm{CH}_{4} \text { breath test. } \\
\text { Positivity was defined as an increase } \\
\text { in } \mathrm{H}_{2} \text { of } \geq 20 \mathrm{ppm} \text { or } \mathrm{CH}_{4} \text { of } \geq 10 \\
\mathrm{ppm} \text { over baseline before the first } \\
60 \text { min. } \\
\text { Real-time polymerase chain reaction } \\
\text { (results are described in } \\
\text { aetiology section) }\end{array}$ & $61.0 \%$ \\
\hline Belei et al. (51) & 2017 & $\begin{array}{l}\text { Children with overweight or } \\
\text { obesity aged } 10 \text { to } 18 \text { years and } \\
\text { age- and sex-matched controls }\end{array}$ & Cross-sectional & $\begin{array}{l}\text { Cases: } 125 \\
\text { Controls: } 120\end{array}$ & $\begin{array}{l}\text { GHBT } \\
\text { Positivity was defined as an increase } \\
\text { in } \mathrm{H}_{2} \text { in two consecutive } \\
\text { measurements of at least } 15 \mathrm{ppm} \\
\text { over baseline. }\end{array}$ & $\begin{array}{l}\text { Cases: } 37.6 \% \\
\text { Controls: } 3.3 \%\end{array}$ \\
\hline
\end{tabular}


TABLE 1 | Continued

\begin{tabular}{|c|c|c|c|c|c|c|}
\hline References & Year & Study population & Study design & $\begin{array}{l}\text { Sample size } \\
\text { (n) }\end{array}$ & $\begin{array}{l}\text { Diagnostic tests and criteria for } \\
\text { positivity }\end{array}$ & $\begin{array}{l}\text { Reported SIBO } \\
\text { prevalence* }\end{array}$ \\
\hline Galloway et al. (18) & 2018 & $\begin{array}{l}\text { Children with intestinal failure } \\
\text { aged } 9 \text { months to } 17 \text { years. }\end{array}$ & Prospective & Cases: 14 & $\begin{array}{l}\text { Duodenal aspirate culture. } \\
\text { Positivity was defined as } \\
\geq 10^{5} \mathrm{CFU} / \mathrm{ml} \text {. }\end{array}$ & $43 \%$ \\
\hline Gaffar et al. (26) & 2018 & $\begin{array}{l}\text { Children living in a } \\
\text { disadvantaged urban community } \\
\text { aged } 12 \text { to } 18 \text { months. }\end{array}$ & Prospective & Cases: 194 & $\begin{array}{l}\text { GHBT } \\
\text { Positivity was defined as an increase } \\
\text { in } \mathrm{H}_{2} \text { of } \geq 12 \text { ppm over baseline } \\
\text { measurement on any single } \\
\text { post-glucose reading. }\end{array}$ & $14.9 \%$ \\
\hline Furnari et al. (52) & 2018 & $\begin{array}{l}\text { Subjects with cystic fibrosis older } \\
\text { than } 2 \text { years. }\end{array}$ & $\begin{array}{l}\text { Randomised, } \\
\text { case-control Trial }\end{array}$ & Cases: 79 & $\begin{array}{l}\text { Glucose } \mathrm{H}_{2} / \mathrm{CH}_{4} \text { breath test. } \\
\text { Positivity was defined as either a } \mathrm{H}_{2} \\
\text { basal level of } \geq 12 \mathrm{ppm} \text {, a peak of } \mathrm{H}_{2} \\
\text { excretion of } \geq 10 \mathrm{ppm} \text { over baseline } \\
\text { during the test, or a } \mathrm{CH}_{4} \text { level of } \geq 12 \\
\text { ppm at any point time. }\end{array}$ & $31.6 \%$ \\
\hline Vonaesch et al. (6) & 2018 & $\begin{array}{l}\text { Stunted children aged } 2 \text { to } 5 \\
\text { years and healthy controls. }\end{array}$ & Cross-sectional & Cases: 46 & $\begin{array}{l}\text { Duodenal aspirate culture. } \\
\text { Positivity was defined as } \geq 10^{5} \\
\text { CFU/ml. } \\
16 S \text { rRNA sequencing (results are } \\
\text { described in the text) }\end{array}$ & Cases: 96\% \\
\hline
\end{tabular}

${ }^{*} A$ few studies also evaluated the incidence of SIBO in children (indicated in parenthesis). GHBT, glucose hydrogen breath test; LHBT, lactulose hydrogen breath test; $\mathrm{H}_{2}$, hydrogen; $\mathrm{CH}_{4}$, methane; $\mathrm{CO}_{2}$, carbon dioxide; ppm, parts per million.

chain fatty acid production $(6,65)$; intestinal and systemic inflammation $(16,25,66)$; and increased gut permeability (Figure 3). It should be noted that a recent systematic review (53) and clinical study (25) found conflicting and contradictory evidence supporting effects of gut permeability.

\section{RISK FACTORS FOR SIBO \\ Acid-Suppressive Therapies}

Gastric acid plays a crucial role in preventing pathogens from colonizing the human alimentary tract, particularly the proximal portions (67). Several extrinsic and intrinsic factors are known to alter this natural barrier (68), with one of them being medication-induced hypochloridria, caused most frequently by proton pump inhibitors (PPIs). PPIs are commonly prescribed for the treatment of gastroesophageal reflux disease (GERD) and, sometimes, for gastroesophageal reflux (GER) in children (69). These drugs decrease gastric acid secretion by blocking the enzyme $\mathrm{H}^{+} / \mathrm{K}^{+}$-adenosine triphosphatase located in the apical membrane of parietal cells (70). It has been estimated that approximately 34\% (69) of paediatric patients treated with PPIs develop adverse effects, including infectious diarrhoea, Clostridium difficile infection, respiratory infections, or SIBO (71-77). In addition, PPIs have also been shown to alter the faecal gut microbiota of children and adults $(78,79)$. In theory, the resultant acid suppression creates a more favourable environment for bacteria to overgrow -particularly Grampositive, aerobic bacteria (31)-, leading to the development of SIBO. However, a recent observational study (6) found contradictory evidence: despite the high prevalence of SIBO seen in the patient cohort (i.e., 96\%), gastric $\mathrm{pH}$ was found to be in the acidic range (i.e., $\mathrm{pH} 2.7$ ). It is important to note that $\mathrm{pH}$ measurements were only obtained from the study group and lacked normal reference values for comparison.

To date, four studies have assessed SIBO risk in children taking acid-suppressive treatments (80). Cares et al. (7) used the glucose $\mathrm{H}_{2} / \mathrm{CH}_{4}$ breath test to determine the presence of SIBO in children taking PPIs for a prolonged time (i.e., longer than 6 months). $77 \%$ of patients took a PPI for over 12 months, and SIBO was diagnosed in $8.9 \%$ and $3.7 \%$ of PPI-subjects and controls, respectively. Moreover, Sieczkowska et al. (10) enrolled children with histology-proven peptic esophagitis in a 3month trial of omeprazole treatment. A glucose hydrogen breath test (GHBT) was performed before and after PPI treatment, revealing that $22.5 \%$ developed SIBO as a result of the therapy. Furthermore, Rosen et al. (8) cultured the gastric fluid of children taking PPIs for at least 4 weeks and whose last dose was taken within $24 \mathrm{~h}$ of sampling. Compared to the control group, the PPI-group was found to have a significantly higher prevalence of gastric overgrowth (18 vs. $46 \%$, respectively), mainly caused by potential pathogens such as Staphylococcus and Streptococcus. In a double-blind, placebo-controlled randomised clinical trial, Hegar et al. (9) randomly assigned children to one of two 4-week treatment groups: omeprazole + placebo group or omeprazole + probiotic. SIBO had been excluded at baseline in all. Following the 4-week intervention, a second GHBT indicated that SIBO was present in $33 \%$ and $26 \%$ of omeprazole/probiotic group and omeprazole/placebo group, respectively.

Two metanalyses $(81,82)$ of adult patients evaluated the association between PPI therapy and SIBO risk. The most recent study by $\mathrm{Su}$ et al. (81) included 19 observational studies with a total of 7,055 adult subjects in the analysis. Although there was a significant degree of heterogeneity amongst the studies included, after adjusting for study quality, the authors concluded that PPI 


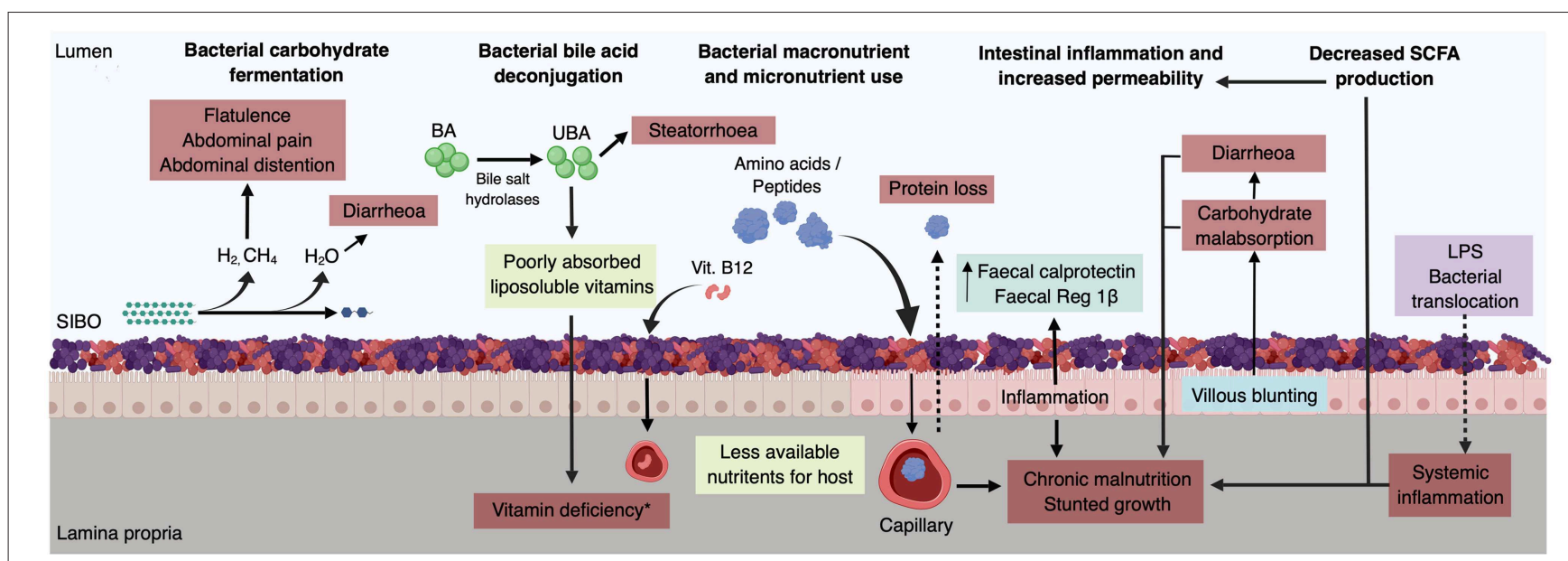

FIGURE 3 | Mechanisms through which SIBO affects the host. The dotted arrows indicate increased intestinal permeability. ${ }^{*}$ Includes vitamin A, D, E, and vitamin B 12. Vitamin $\mathrm{K}$ is synthesised by the gut microbiota, and thus its deficiency in this context is very unlikely. BA, bile acids; UBA, unconjugated bile acids; LPS, liposaccharides. Created with BioRender.com.

therapy was associated with a moderately increased risk for SIBO (odds ratio 1.71, 95\% CI 1.20-2.43). The second meta-analysis (83) included 11 studies [all of which were included in the metanalysis by $\mathrm{Su}$ et al. (81)] with a total of 3,134 adult subjects. Again, the authors found a statistically significant association (odds ratio, 2.282, 95\% CI 1.238-4.205) between PPI therapy and SIBO, but only when diagnosis was made with "highly accurate testing modality," such as duodenal/jejunal aspirate culture. It is important to mention, however, that all the studies included in both metanalyses were observational in nature and culture or breath test-based approaches were used for SIBO diagnosis.

In conclusion, it appears that acid suppressive therapies, and in particular PPIs, seem to be a risk factor for SIBO development, but only when this is assessed by culture approaches. However, it is important to mention that the data are limited by the overall low odds ratios $(\sim 2)$ and the lack of controls. Thus, until better data are available, it is of paramount importance that PPI prescriptions in children with possible GERD are judicious, and perhaps more importantly, that their use is avoided in children with GER $(72,83)$.

\section{Intestinal Motility Disturbances}

In addition to the acidic environment created by the gastric acid, gut motility is critical to preventing SIBO. One motor event, the migrating motor complex (MMC), a cyclic motor pattern that occurs during the interdigestive state, plays an important role in preventing the development of bacterial overgrowth within the small intestine (83). In fact, the MMC is commonly referred to as the "intestinal housekeeper," emphasising its role in gastrointestinal health (84). Under physiological conditions, the MMC sustains the aboral progression of luminal content in the small intestine between meals, thereby preventing stasis and SIBO. On this basis, an absent or disrupted MMC may lead to bacterial overgrowth (84).

The typical example of a disease with gut dysmotility leading to SIBO is systemic sclerosis, with $\sim 40 \%$ of adult patients being affected (54). Despite the relatively high prevalence of gastrointestinal symptoms in children with juvenile systemic sclerosis (jSS) (85), to our knowledge, no studies have investigated the association of SIBO with jSS.

A somewhat more common example of gut dysmotility associated with increased risk of SIBO is cystic fibrosis (CF) (86). Here there is limited clinical data from studies in children. Lisowska et al. (11) found a significantly higher SIBO prevalence in patients with CF compared with non-CF subjects (37 vs. $13 \%$, respectively), and so did Fridge et al. (12) who found a significantly higher prevalence in CF-subjects than controls (56 vs. $20 \%$, respectively). Both studies used the hydrogen breath test (HBT) for SIBO diagnosis. Moreover, Lewindon et al. (13) evaluated, with the HBT, SIBO prevalence and orocecal transit time of children with CF. Interestingly, compared with the two control groups (i.e., healthy children and non-CF patients), CFsubjects had a significantly higher SIBO prevalence and their orocecal transit times were significantly longer than those of healthy individuals. More recently, Furnari et al. (52) found a $31 \%$ SIBO prevalence in both children and adults with CF. Preclinical studies in murine models have demonstrated that CF-mice have a higher SIBO prevalence than wild-type mice (87), which is thought to be mainly caused by two factors: (1) slowed intestinal transit -possibly due to unabsorbed lipids leading to a triggering of the "ileal brake" - and/or smooth muscle dysfunction $(86,88)$; and (2) mucus accumulation which acts as an anchor for bacteria, thereby facilitating their overgrowth $(87,89)$. Thus, the multifactorial nature of $\mathrm{CF}$, including gut dysmotility and impaired mucus clearance, seems to put patients at a higher risk of SIBO development.

Constipation has been shown to be associated with SIBO. However, the causative or consequential nature of this interaction is unclear. In theory, a slower orocecal transit in constipation may fail to clear the luminal content, thereby increasing SIBO risk. On the other hand, methane, a biologically active gas produced instead of hydrogen by some individuals from bacterial 
fermentation of carbohydrates, can delay intestinal transit, which in turn may lead to constipation. We identified three studies that investigated the role of SIBO in children with constipation. Ojetti et al. (14) diagnosed SIBO in 39\% (7/18) of children with myelomeningocele, a disease associated with constipation. Interestingly, the authors found that all methane producers had a delayed orocecal transit time. Moreover, Leiby et al. (15) found a $42 \%$ (21/50) SIBO prevalence in children with retentive faecal incontinence, of whom, eight had methanogenic SIBO, 11 had hydrogen-type SIBO, and two had mixed (methane and hydrogen)-type SIBO. In addition, $48 \%$ of patients with faecal incontience were found to have high basal methane concentrations (>10 ppm) as compared with $10 \%$ of control subjects. Furthermore, Fontanele Soares et al. (20) investigated the relationship between methane production and colonic transit time in children with constipation. Methane production was found in $73.5 \%(25 / 34)$ of children with constipation and soiling as compared with $1 \%$ of children with constipation alone.

The notion that a slowed intestinal transit may predispose to SIBO is supported by two recent studies in adults $(90,91)$. In the most recent study, by Revaiah et al. (90), two patient groups (i.e., PPI-group and PPI + prokinetic group) underwent a GHBT and lactulose hydrogen breath test (LHBT) and orocecal transit time assessment. Interestingly, SIBO was documented more frequently in the PPI alone group than in the PPI + prokinetic group, and SIBO-positive patients had slower orocecal transit times than SIBO-negative patients. However, it is important to note that the overall SIBO prevalence was only $8.8 \%$ (13 subjects) and, even though the authors measured both hydrogen and methane, it was not specified whether the three patients with methane-positive SIBO had normal or delayed orocecal transit times. Furthermore, Sarosiek et al. (91) prospectively enrolled 29 female patients with functional constipation in a 2 -week lubiprostone trial. Gastrointestinal transit and SIBO were assessed by the wireless motility capsule (WMC) and lactulose hydrogen/methane breath tests, respectively. At baseline, $68 \%$ of patients had increased levels of both hydrogen and methane, suggesting SIBO. After treatment, $41 \%$ of patients became SIBO-negative, which was paralleled by a $30 \%$ increase in small bowel transit time. However, it is important to mention that the authors considered methane positivity as an increase of $\geq 3 \mathrm{ppm}$, which differs from the current guidelines in which methane positivity is defined as an increase of $\geq 10 \mathrm{ppm}$ (92). These findings are difficult to interpret for two reasons: (1) all patients had constipation and were methane producers at baseline (i.e., methane production of $\geq 3$ ppm); thus, this suggests constipation may have been caused by intestinal methane production rather than constipation leading to SIBO; or simply, the methane values present in these patients could be physiological; and (2), the fact that lubiprostone "cured" $41 \%$ of SIBO patients suggests that by increasing the intestinal transit-and thus intraluminal clearance-faecal stasis decreases, which prevents SIBO development.

\section{Anatomical Alterations}

Anatomical boundaries are crucial for maintaining a harmonized microbial community within the human alimentary tract, particularly the integrity of the ileocecal valve. Absence or dysfunction of the ileocecal valve has been shown to predispose patients to SIBO, as colonic bacteria are thought to be "backwashed" into the small intestine, thereby leading to coliform-type SIBO development (31).

Paediatric intestinal failure is a disease characterised by increased SIBO prevalence, which is thought to be due to a multifactorial process that includes altered intestinal motility and anatomy, resection of the ileocecal valve, and use of antacids $(93,94)$. Only four recent studies have investigated SIBO incidence/prevalence in children with intestinal failure (or short bowel syndrome) (16-19). The most recent study by Hong et al. (19) found a $78 \%$ SIBO prevalence in their patient cohort of children who underwent extensive small bowel resections due to midgut volvulus. Interestingly, only $22 \%$ of patients had a functional ileocecal valve. Moreover, Galloway et al. (18) diagnosed SIBO by duodenal aspirate cultures in $43 \%$ of patients with intestinal failure, caused mainly by gastroschisis, atresias, and necrotizing enterocolitis. Of these, only one subject had an ileocecal valve (16\%). Furthermore, Gutierrez et al. (17) diagnosed SIBO in $70 \%$ of patients with intestinal failure due to various surgical and non-surgical aetiologies. Although the authors did not find a significant difference regarding SIBO prevalence between children with and without ileocecal valve, they did find a significant association between parenteral nutrition (PN) use and SIBO. The fourth study by Cole et al. (16) found a 50\% SIBO incidence in their patient cohort of children with short bowel syndrome caused by necrotizing enterocolitis. Of these, $40 \%$ of children had a functional ileocecal valve. In line with the findings by Gutierrez et al. (17), another interesting study (95) that evaluated the faecal gut microbiota of children with short bowel syndrome by next generation sequencing found that children who were on PN had decreased diversity and increased numbers of Proteobacteria as compared with those who were weaned from PN. None of the PN-patients had an ileocecal valve and, of these, four out five patients were being evaluated for SIBO and were being treated with antibiotics, which may explain the microbiota perturbations observed.

Taken together, these findings demonstrate that paediatric intestinal failure is a multifactorial process that increases the risk of SIBO, as these children have a disrupted intestinal anatomy, physiology, and microbiota which is frequently exposed to antacids and antibiotics. Resection of the ileocecal valve, in particular, appears to be a common finding in children with intestinal failure and SIBO, strongly suggesting the role of this structure in SIBO prevention. In line with this, Roland et al. (96) investigated the ileocecal junction pressure by WMC and the presence of SIBO by the LHBT and small bowel aspirate cultures. Interestingly, the authors found a combination of SIBO-predisposing factors in their patient cohort: (1) the small bowel transit time in SIBO-patients was significantly slower that those without SIBO; (2) the gastric $\mathrm{pH}$ was significantly higher in SIBO-patients than those without SIBO; and (3) the mean ileocecal junction pressure was significantly lower among SIBO-patients than those without SIBO. Thus, these findings reinforce the fact that an "incompetent" ileocecal valve predisposes to SIBO and emphasise the multifactorial nature of the disease. 


\section{Impoverished Conditions and Poor Socioeconomic Status}

Impoverished conditions, which are commonly associated with a lack of basic sanitation services such as clean water, appropriate sewage, and collection of household garbage, may be a risk factor for SIBO. To our knowledge, six studies [one from Myanmar (21), three from Brazil (22-24), and two from Bangladesh $(25,26)]$ have investigated this association in the paediatric population.

Pereira et al. (21) investigated the prevalence of SIBO in children from a Burmese village (Myanmar) by using the LHBT. Around $85 \%$ of the village's population obtained drinking water from surface wells and ponds, and approximately $10 \%$ used rain water for the same purposes (97). The authors diagnosed SIBO in $27 \%$ of cases (53/195), with males being more commonly affected than females. Moreover, dos Reis et al. (22) found a significantly higher SIBO prevalence in children living in a slum as compared with controls living in households with appropriate sanitation services (37.5 vs. $2.1 \%$, respectively). In addition, Mello et al. (23) also found a significantly higher SIBO prevalence in the slum-group compared with their socioeconomically advantaged counterparts (30.9 vs. $2.4 \%$, respectively); however, it is important to note that the authors did not find statistically significant differences in the environmental variables (i.e., water contamination with coliforms, access to public water network, access to public sewage, and public collection of household garbage) between the SIBO-positive and SIBO-negative slum subgroups. The second and more recent study by Mello et al. (24) assessed SIBO prevalence and analysed the faecal gut microbiota of children residing in a Brazilian slum. Roughly $60 \%$ of children were found to have SIBO, and their faecal gut microbiota analyses showed a significantly higher number of Salmonella spp. and lower numbers of Firmicutes. Donowitz et al. (25), who investigated SIBO prevalence in 90 Bangladeshi children belonging to the lowest socioeconomic strata, reported that $16.7 \%$ had a positive GHBT and that the odds of developing SIBO were increased by the presence of an open drain/sewer outside the home (odds ratio, 4.78 ; 95\% confidence interval, 1.06 to 21.62 ). More recently, Gaffar et al. (26) conducted a prospective nutritional intervention study on stunted and at-risk-of-stunting Bangladeshi children living in an urban slum (98), and found SIBO in $14.9 \%$ of subjects.

Taken together, these findings demonstrate that poor sanitation conditions, particularly contaminated water exposure, may expose children to a higher risk of developing SIBO. However, none of these studies provided a clear pathophysiological mechanism by which such unsanitary conditions predispose children to the disease. Donowitz et al. (55) proposed a mechanism of SIBO development in the setting of poor sanitary living conditions. The authors hypothesised that repeated exposure to abnormal levels of liposaccharides found in soil and drinking water may disrupt the MMC, causing faecal stasis (as seen in patients with gut dysmotility), thereby leading to SIBO development. While this theory appears to have some biological plausibility, to date, no studies have evaluated it.

\section{Other SIBO Risk Factors}

Immunodeficiency and coeliac disease (CD) have also been regarded as potential risk factors for SIBO development. As for immunodeficiency, we only identified one small-scale study (44) from 1990, which was conducted on children with immunodeficiency syndromes (i.e., IgA deficiency, hypogammaglobulinemia, and $\mathrm{T}$ cell defects). The most common clinical manifestation was chronic diarrhoea and SIBO was diagnosed in $41 \%$ of patients via jejunal aspirate culture. Moreover, in a more recent study (99), $4 \%(n=12 / 296)$ of young adults with chronic diarrhoea and malabsorption syndrome were found to have hypogammaglobulinemia. Of these, 25\% ( $n=$ 3/12) were diagnosed with SIBO. Although these findings show a relatively high SIBO prevalence in children and young adults with immunodeficiency syndromes, recent, large-scale studies are needed in order to support this association. As for CD, a recent systematic review (100) of adult patient studies found a high SIBO prevalence in patients with CD $(20 \%$ pooled mean prevalence). The authors concluded that SIBO may be more common in patients with $\mathrm{CD}$ when symptoms do not improve after a gluten-free diet. We identified only two studies $(101,102)$ that characterized the microbiota composition and diversity of children with CD: subjects with active CD were found to have a higher abundance of members of the phylum Proteobacteria (101) and lower ecological indexes of genus Lactobacillus (102) as compared with healthy and non-active CD patients. Although these studies did not set out to evaluate SIBO per se and as such did not report CFU/g, the higher Proteobacteria abundance and lower ecological indexes of genus Lactobacillus seen in children with CD may indicate a disturbed microbial ecosystem. Certainly, a study that evaluates the presence of SIBO in coeliac children, either by the $\mathrm{H}_{2} / \mathrm{CH}_{4}$ breath test or small intestinal aspirate culture, would be of great interest.

It is important to note, however, that SIBO can develop even in the absence of any of the aforementioned risk factors. In line with the findings by Boissieu et al. (3) and our own experience, many children who test positive for SIBO are "healthy" and have no evident risk factors. There are clearly many questions to be addressed by future studies regarding the risk factors for SIBO in children.

\section{AETIOLOGY OF PAEDIATRIC AND ADULT SIBO}

SIBO can be caused by archaea or bacteria, by one or more microorganisms, by Gram-positive or Gram-negative bacteria, and by anaerobic or aerobic microorganisms (31). Pistiki et al. (103) conducted a cross-sectional study in which patients underwent duodenal aspirate cultures for the diagnosis of SIBO with a diagnostic threshold of $>10^{3} \mathrm{CFU} / \mathrm{mL}$. SIBO was diagnosed in $20 \%$ of cases, being caused by one microorganism in $54.7 \%$ of cases and by two microorganisms in the remainder. In addition, the vast majority of bacterial isolates belonged to the phyla Proteobacteria and Firmicutes, with the most common being Escherichia coli, Enterobacter spp., Klebsiella spp., Pseudomonas aeruginosa, Staphylococcus aureus, Acinetobacter 
baumannii, Stenotrophomonas maltophilia, Citrobacter freundii, Serratia marcescens, and Enterococcus faecium (in descending order of frequency). In turn, Pyleris et al. (104) conducted a study with the same diagnostic methodology, finding SIBO in $19.4 \%$ of adult subjects. Likewise, most bacterial isolates were members of the Proteobacteria and Firmicutes phyla (Escherichia coli, Enterococcus spp. Klebsiella pneumoniae, Proteus mirabilis, Acinetobacter baumannii, Citrobacter freundii, and Serratia marscecens), and in $75 \%$ of cases the overgrowth was due to one microorganism. In the remainder of cases, SIBO was caused by two microorganisms, with the most common dyads being E. coli + K. pneumoniae and E. coli + Enterococcus spp. Furthermore, Gutierrez (17) conducted a retrospective study on children with intestinal failure who underwent duodenal aspirate cultures. SIBO was diagnosed in $70 \%$ of cases by using a more stringent diagnostic threshold of $>10^{5} \mathrm{CFU} / \mathrm{mL}$. Again, the most common causative microorganisms were members of the Proteobacteria and Firmicutes phyla, with the most common being E. coli, Streptococcus viridans, $K$ pneumoniae, Enterococcus spp., and Pseudomonas aeruginosa. The overgrowth was due to more than one bacterium in a minority of patients. Moreover, Galloway (18) diagnosed SIBO in $43 \%$ of children with intestinal failure, of whom five out of six patients had overgrowth due to two different microorganisms and only one had overgrowth caused by one microorganism, with Enterococcus and Klebsiella being the most frequently isolated bacteria.

More recently, Ghoshal et al. (105) conducted a crosssectional study on adult subjects with non-alcoholic steatohepatitis (NASH) who underwent a GHBT coupled with jejunal aspirate cultures. The authors defined SIBO as a bacterial growth of $\geq 10^{5} \mathrm{CFU} / \mathrm{mL}$ and low-grade bacterial overgrowth as $\geq 10^{3} \mathrm{CFU} / \mathrm{mL} ; 20$ and $60 \%$ of cases were diagnosed with SIBO and low-grade bacterial overgrowth, respectively. Amongst the SIBO cases, Proteobacteria (Pseudomonas aeruginosa, Klebsiella pneumonia, and Acinetobacter spp.) were the most commonly isolated microorganisms followed by members of the Firmicutes phylum (Streptococcus spp. and Enterococcus faecalis); $20 \%$ of cases were due to overgrowth of more than one microorganism.

Taken together, these findings demonstrate that in most cases, SIBO is caused by a single microorganism that belongs to the Proteobacteria phylum (37), particularly coliform bacteria such as E. coli and Klebsiella spp. However, it is important to consider three aspects: (1) culture-dependant approaches were used in these studies, which means that there was a risk of missing bacteria that remain difficult to culture under clinical laboratory conditions; (2) only two studies were conducted on children (17), and (3) SIBO was studied in a wide spectrum of clinical contexts, such as IBS, intestinal failure, and nonalcoholic steatohepatitis. Thus, the specificity of such microbiota alterations for SIBO must be interpreted in the context of these potentially important confounders.

Next generation sequencing (NGS) methods such as $16 \mathrm{~S}$ ribosomal RNA (rRNA) sequencing have become a highresolution and relatively cost-effective way to study the human gut microbiome (106-108). To our knowledge, only one study in children (6) has used these methods to evaluate the gut microbiota in the context of SIBO. Vonaesch et al.
(6) conducted a novel, cross-sectional study on stunted and healthy children from Madagascar and Central African Republic (CAR), in which 16S rRNA amplicon sequencing was used to analyse the faecal gut microbiota composition of both groups and to confirm the presence of bacteria identified by gastric and duodenal fluid aspirate cultures-these were only obtained from the stunted group due to ethical reasons. The authors used the higher diagnostic threshold for SIBO diagnosis (i.e., $>10^{5} \mathrm{CFU} / \mathrm{mL}$ ). Despite this, SIBO was diagnosed in 96\% of stunted children (Madagascar: 100\%; and CAR: 88\%) and, interestingly, the most common causative microorganisms were oropharyngeal colonizers, such as Streptococcus spp., Staphylococcus spp., Haemophilus spp., Moraxella spp., and Neisseria spp. In addition, microbiota sequencing showed overrepresentation of oropharyngeal species (e.g., Streptococcus spp., Haemophilus spp., Neisseria spp., Rothia spp., Actinomyces spp., and Gemella spp.) and enteropathogens (e.g., Escherichia coli, Shigella, and Campylobacter), as well as underrepresentation of butyrate producers (e.g., Clostridia spp.) in stunted children compared with controls. In contrast with the studies described above (17, 103-105), however, most bacterial overgrowths were caused by members of the Firmicutes phylum followed by the Proteobacteria phylum.

\section{CLINICAL FEATURES AND COMPLICATIONS OF SIBO IN CHILDREN}

Paediatric SIBO is a heterogenous disorder that manifests itself through non-specific symptomatology, including gastrointestinal and non-gastrointestinal symptoms $(31,109)$. The most common signs and symptoms reported in the literature are chronic abdominal pain, abdominal distention, diarrhoea, flatulence, belching, steatorrhea, fetid stools, mucus in stools, fatigue, nausea, and stunted growth (Table 1) (2-6).

\section{SIBO and Functional Gastrointestinal Disorders}

It is always challenging to discuss functional gastrointestinal disorders (FGIDs) and their possible interaction with an organic aetiology, such as SIBO. A small number of observational studies have evaluated the association between FGIDs and SIBO in the paediatric population.

Korterink et al. (4) determined the presence of SIBO in children with abdominal pain-related functional gastrointestinal disorders [i.e., irritable bowel syndrome (IBS), functional abdominal pain (FAP), functional dyspepsia (FD), and FAP syndrome] by using the GHBT. Amongst the $14.3 \%$ SIBOpositive subjects, the most common symptoms were fatigue (75\%), altered defecation pattern (71\%), nausea $(68 \%)$, and bloating (66\%). However, only altered defecation pattern, loss of appetite, and belching were significantly higher than SIBOnegative subjects; diarrhoea and flatulence did not reach statistical significance. Furthermore, Collins et al. (46) also used the hydrogen/methane breath test to diagnose SIBO in their cohort of children with chronic abdominal pain (i.e., FD, IBS, and FAP). Ninety one percent of cases and 35\% of healthy controls 
had a positive breath test, respectively. Surprisingly, there were no differences in the presence of gastrointestinal symptoms such as bloating, gas, incomplete evacuation, constipation, diarrhoea, mucous in stool, or straining, between SIBO-positive and SIBOnegative subjects; however, it is important to mention that the comparison was disproportional between the two groups (68 vs. 7 patients, respectively). Moreover, Scarpellini et al. (45) evaluated the prevalence of SIBO in children with IBS by the lactulose hydrogen/methane breath test, finding a higher prevalence of SIBO amongst IBS sufferers compared to their healthy counterparts (65 vs. $7 \%$, respectively). Taken together, these findings demonstrate that SIBO is a frequent underlying diagnosis in children with functional abdominal pain disorders (i.e., IBS and FD), thus suggesting a role in their pathogenesis.

The IBS-SIBO interaction has attracted a tremendous amount of research in the last decade, and thus it deserves special attention. A recent systematic review and metanalysis (110) of observational studies in adults estimated the prevalence and determined predictors of SIBO in IBS. The authors found an overall pooled SIBO prevalence of $38 \%$ (95\% CI 32-44) as well as a 4.7 (95\% CI 3.1-7.2) pooled OR of SIBO in IBS subjects as compared with healthy controls. Surprisingly, PPI use was not associated with SIBO. Even though a growing body of literature shows a clear association between the two disorders, it is unclear whether SIBO precedes IBS or vice versa $(111,112)$. Thus, until better data are available, children presenting with IBS-like symptomatology may merit SIBO-diagnostic workup, such as a $\mathrm{H}_{2} / \mathrm{CH}_{4}$ breath test [SIBO's role in IBS is comprehensively reviewed elsewhere $(61,113)]$.

Constipation, another FGID, has been associated with intestinal methane production in adults and children (methanogenic SIBO) (114) Indeed, a 2011 metanalysis (115) of nine studies (1,277 subjects) found a significant association between methane on breath test and constipation (OR 3.51, CI 2.00-6.16). Moreover, Pimentel et al. (116) demonstrated this association in animal and human models: intraluminal infusion of methane reduced small bowel transit by $59 \%$ in canine models as compared with controls, and methane was also found to increase intestinal contractile activity in guinea pigs and in patients with IBS. In contrast, Mello et al. (23) did not find an association between methane and constipation in their patient cohort of children living in a slum; in fact, none of these children had constipation despite a $30 \%$ prevalence of methanogenic SIBO. More recently, Ghoshal et al. (117) investigated the effect of rifaximin on breath methane and colonic transit in adult patients with constipation. The authors found that a larger percentage of patients with chronic constipation were methane producers $(>10 \mathrm{ppm}$ ) and had slower colonic transit times as compared with controls. Methane producers $(n=13)$ were randomly assigned into two groups: rifaximin group (14-day trial) and placebo group. After treatment, the rifaximin group had a significantly lower area under the curve for methane production compared with the placebo group, and colonic transit time normalized in $66 \%$ of cases as compared with the placebo group, in whom colonic transit time never normalized. Thus, these findings support the association between methanogenic SIBO and constipation. The most important question to be answered is whether it would be cost-effective to perform methane breath tests on all children with "functional" constipation, considering the relatively high prevalence of the disease. What we know from small scale studies is that children with constipation and retentive faecal incontinence are more likely to be methane producers than children with constipation alone $(15,20)$. Thus, possibly, these children may benefit from antibiotic therapy. However, large scale, prospective studies are warranted in order to (1) clarify the relation between methanogenic SIBO and constipation, and (2) determine whether children with methanogenic SIBO and constipation may benefit from antibiotic treatment.

\section{SIBO and Systemic Disorders}

Increasing evidence suggests that SIBO may be implicated in the complex pathophysiology of stunted growth $(6,25)$ and environmental enteric dysfunction (EED; formerly known as environmental enteropathy) (24, 55, 56, 60). Stunting affects $>30 \%$ of children under five from low income countries (118). As shown in Figure 3, intraluminal competition for micro and macronutrients between the excessive bacterial biomass and the host (119), as well as other SIBO-induced factors (e.g., diarrhoea, carbohydrate malabsorption, protein loss, increased intestinal permeability, intestinal and systemic inflammation), can lead to a negative caloric balance in the host, thereby, resulting in stunted growth and malnutrition. Such factors, too, characterise EED, thus it appears that SIBO may play an important role in EED's pathogenesis $(6,120)$. Vonaesch et al. (6) diagnosed SIBO in $96 \%$ of their patient cohort of children with stunting by the GHBT. In addition, Donowitz et al. (25) found a 16.7\% SIBO prevalence in Bangladeshi children using the same diagnostic methodology. Taken together, these findings suggest a possible role of SIBO in stunting and EED's pathogenesis. Thus, it may be worthwhile to perform a hydrogen/methane breath test as part of the clinical approach to children with these diseases.

Moreover, although deficiencies of liposoluble vitamins (A, $\mathrm{D}$, and E) and vitamin B 12 haven been documented in the adult population $(121,122)$, no studies have explored this issue in children with SIBO-a study assessing vitamin B12 and liposoluble vitamin status in children affected by SIBO would be of great interest. Menaquinone (vitamin K2) is produced by the gut microbiota (123), and thus from a physiological standpoint it would be contradictory to assume that vitamin K deficiency would arise in a bacterial-abundant environment. However, a recent case report described a 17 -year-old female with vitamin $\mathrm{K}$ deficiency possibly caused by SIBO. The authors speculated that the vitamin $\mathrm{K}$ deficiency seen in this patient may have been the result of reduced menaquinone-producing bacteria, expansion of vitamin K-consuming bacteria, or severe malabsorption (124). Further gut metabolome studies (125) are needed to elucidate SIBO's role in vitamin deficiencies.

Currently, there are no guidelines regarding diagnosis or treatment of SIBO in children. Given the heterogenous and nonspecific nature of the disease, it is sometimes challenging to decide in whom to initiate SIBO diagnostic work-up. However, it is of paramount importance to first rule out signs and symptoms (i.e., red flags) that may indicate diseases other than SIBO. 


\section{DIAGNOSIS}

SIBO can be diagnosed by invasive and non-invasive methods. The non-invasive methods include breath tests, while invasive methods comprise culture-dependant and culture-independent approaches.

\section{Hydrogen and Methane Breath Testing}

Although subject to debate and controversy (126-128), the $\mathrm{H}_{2}$ and $\mathrm{CH}_{4}$ breath tests are increasingly being used due to their widely availability in healthcare facilities, because they are inexpensive, practical, and non-invasive (which is extremely important in paediatrics), and because the results can be interpreted on the same day of the test [the $\mathrm{H}_{2} / \mathrm{CH}_{4}$ breath test procedure is thoroughly reviewed elsewhere $(92,129,130)]$. According to the 2017 "Hydrogen and Methane-Based Breath Testing in Gastrointestinal Disorders: The North American Consensus"(92), a panel of 17 experts from North America and the latest consensus in regard to this topic, SIBO diagnosis is suggested when there is an increase in $\mathrm{H}_{2}$ of $\geq 20$ ppm over baseline within the first $90 \mathrm{~min}$ of the test with either lactulose or glucose, or when there is an increase in $\mathrm{CH}_{4}$ of $\geq 10 \mathrm{ppm}$ at any time point of the test (Figure 4). On the other hand, the older Rome Consensus (130) recommends the use of glucose as substrate due to its greater accuracy, and defines SIBO as an increase in $\mathrm{H}_{2}$ of $\geq 12$ above baseline by using the GHBT. A definition of SIBO by using the LHBT was not included in this paper.

In order to understand the mechanisms behind $\mathrm{H}_{2}$ and $\mathrm{CH}_{4}$ breath testing, one must be aware of two concepts: orocaecal transit time and intraluminal gas production. The human body has no means of producing $\mathrm{H}_{2}$ and $\mathrm{CH}_{4}$ other than intraluminal microbial fermentation and methanogenesis, respectively $(92,130-132)$. As previously mentioned, the colonic microbiota represents virtually the whole gut microbiota, most of which is composed of fibre-fermenter anaerobes, mainly those belonging to the Actinobacteria and Firmicutes phyla (133). Undigestible carbohydrates reaching the colon are readily fermented by hydrogenogens ( $\mathrm{H}_{2}$-producing bacteria) (134), and hence a physiological increase in $\mathrm{H}_{2}$ is expected in the colon. Intraluminal $\mathrm{H}_{2}$, in turn, is absorbed into the systemic circulation and is transported to the lungs where it can then be released through exhaled breath (129). Moreover, the orocaecal transit time-the elapsed time between ingestion of a substance until it reaches the caecum - has been shown to be around $90 \mathrm{~min}$ in both adults and children, as assessed by the LHBT (135). Thus, in the presence of SIBO, substrate administration will result in a small bowel $\mathrm{H}_{2}$ peak, occurring before the orocaecal transit time has completed (i.e., $90 \mathrm{~min}$ ).

Glucose and lactulose are the substrates usually used for breath tests to diagnose SIBO. The former is a monosaccharide which is readily absorbed in the proximal small intestine, and the latter is a synthetic, undigestible disaccharide that reaches the caecum intact. In the presence of SIBO, glucose administration will result in a $\mathrm{H}_{2}$ peak which is produced in the small intestine (i.e., <90 min); in addition to this peak, lactulose administration can give rise to a second -colonic- $\mathrm{H}_{2}$ peak: the early peak produced by the bacterial overgrowth in the small intestine and the second one caused by the colonic microbiota fermentation $(92,129)$. However, both substrates have their own advantages and limitations. By using glucose, false negative results can arise in the presence of bacterial overgrowth in the distal small bowel (i.e., ileum), as glucose is readily absorbed proximally. In addition, an increased orocecal transit time can give rise to false positive results as the substrate reaches the colon rapidly, thereby undergoing premature fermentation by colon bacteria-this can occur with both glucose and lactulose (126). False negative results can also arise in the absence of $\mathrm{H}_{2}$-producing bacteria or in the presence of CH4-producing microorganisms (discussed below) (130). Based on a 2008 systematic review (136), the sensitivity and specificity of the GHBT ranged from 20 to $93 \%$ and 30 to $86 \%$, respectively; and the sensitivity and specificity of the LHBT ranged from 31 to $68 \%$ and 44 to $100 \%$, respectively.

Methanobrevibacter smithii, a member of the domain Archaea and the most abundant methanogen in the human alimentary tract produces $\mathrm{CH}_{4}$ as an end product of hydrogen metabolism (hydrogenotrophic methanogenesis), by using one molecule of carbon dioxide and four molecules of $\mathrm{H}_{2}$. The archaeon is extremely oxygen sensitive and relies completely on hydrogenogens for $\mathrm{CH}_{4}$ production, due to its inability to metabolise monosaccharides. For this reason, Methanobrevibacter smithii is considered an "obligate crossfeeder" (131). Furthermore, since the archaeon utilizes $\mathrm{H}_{2}$ to produce $\mathrm{CH} 4$, it can lead to a falsely negative HBT. Thus, it is recommended that both $\mathrm{H}_{2}$ and $\mathrm{CH} 4$ are measured in order to avoid this (92).

In conclusion, despite the limitations of the $\mathrm{H}_{2} / \mathrm{CH}_{4}$ test (128), it remains a useful tool in the diagnosis of paediatric SIBO due to its practical and non-invasive nature. Importantly, there are no reported significant side effects for the hydrogen/methane breath test other than transient abdominal pain or vomiting during the test.

\section{Culture-Dependant Approaches}

Culture-dependent approaches are considered the current gold standard for definitive SIBO diagnosis. A small intestinal (i.e., duodenum or jejunum) aspirate is obtained at upper gastrointestinal endoscopy through a sterile catheter and stored anaerobically prior to culture for both aerobic and anaerobic bacteria. When using the proximal jejunal aspirate culture, a bacterial concentration of $>10^{3} \mathrm{CFU} / \mathrm{mL}$ is regarded as indicative of $\operatorname{SIBO}(92,109)$, although there is some heterogeneity in the literature in this regard and some experts recommend a threshold of $>10^{5} \mathrm{CFU} / \mathrm{mL}$ as more specific (137). Despite being regarded as the gold standard diagnostic method, there are several notable limitations to this approach. Firstly, endoscopyguided aspiration procedures are invasive, expensive, and require specialist input, limiting its availability and application in certain settings. Secondly, we know from microbiome research that standard clinical laboratory culture-based approaches have the potential to detect only a minority of the extant bacterial consortium. In addition, care must also be taken not to contaminate samples or sampling apparatus with oropharyngeal microbes, thereby contributing to false positives. Likewise, 

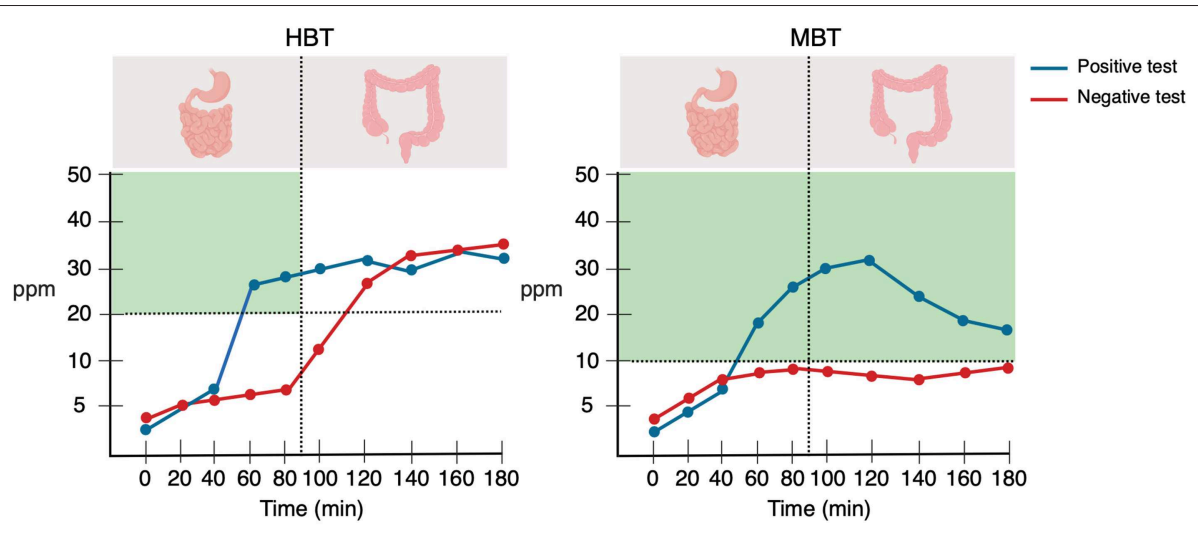

FIGURE 4 | Graphical representation of the hydrogen and methane breath tests. The vertical dotted line indicates the completion of the orocecal transit time, and the horizontal dotted line indicates the current diagnostic thresholds for SIBO. The green shaded areas indicate where the test is considered positive. Created with BioRender.com.

the significant heterogeneity in aspirate sampling protocols are known to impact substantially on the test outcome and accuracy. For example, one study previously used air, rather than nitrogen or carbon dioxide, during endoscopy to recover aspirate samples in suspected SIBO and cultured anaerobic bacteria from just one of 50 samples (138). Other variables include specific site of sampling and volume of aspirate. The lack of standardised protocol and diagnostic consensus for the gold standard investigation undoubtedly contributes to the massive variation in the SIBO prevalence and incidence rates reported in the literature. This, in turn, limits comparability between studies and ultimately hinders research progression in the field. In order for the development of a greater understanding and novel therapies for the disease to arise, the disparities in protocols and diagnostic criteria should first be addressed at a global scale. Finally, in the context of paediatric SIBO, endoscopy of seemingly healthy control children appears to present an obstacle in clinical research studies due to ethical considerations and, therefore, development of less invasive diagnostic approaches is warranted.

\section{SIBO in the Era of Next Generation Sequencing}

As eluded to previously, culture-independent approaches based on NGS technologies have become the most widely applied modalities for studying both the composition and metabolic activity of the gut microbiota. There are several considerations to be addressed when selecting a methodology, including sample type, DNA extraction method, sequencing modality and platform, as well as bioinformatic pipeline [reviewed comprehensively in (43)].

In general, the composition of the gut microbiota is currently most cost effectively studied through $16 \mathrm{~S}$ rRNA sequencing. The $16 \mathrm{~S}$ region is a highly conserved region of rRNA within all taxa of bacteria, which displays sufficient variation and divergence in parts to allow differentiation at the genus level. Although it has been central to the progression of the field of microbiome research, 16S rRNA sequencing is crucially limited in the fact that it does not generate absolute data on quantities of bacteria, but rather provides investigators with a relative abundance of each taxa within a sample. The second modality which is indeed worthy of consideration is metagenomic shotgun sequencing. While 16S rRNA sequencing provides an overview of microbiota composition, metagenomic shotgun sequencing goes a step further by telling us who is there and what are they capable of in metabolic terms.

Although such sequencing capabilities are now commonplace in microbiological and medical research laboratories the globe over, uptake and application to SIBO research has been comparatively slow and, as a result, there is a dearth of relevant clinical data available. Despite this, several clinical studies which targeted alternate, but related, gastrointestinal disorders have provided some intriguing data on the disorder. In line with this, some small studies have reported on the gut microbiome of IBS cohorts, many of which were confirmed to suffer from concomitant SIBO. One such study investigated the faecal microbiota of a cohort of 30 Chinese patients with diarrhoea-predominant IBS, 14 of which were also confirmed to have SIBO by LHBT (139). At baseline, this cohort displayed reduced microbiota diversity, increased relative abundances of Bacteroidetes and decreased relative abundances of Firmicutes when compared to the healthy controls. In addition, the IBS cohort was shown to have reduced relative abundances of the genus Lactobacillus, as well as several genera associated with butyrate production. The investigators subsequently implemented a 2-week course of rifaximin, after which clinical symptoms improved and repeat LHBT demonstrated remission in $65 \%$ of the SIBO-positive subjects. However, the microbiota post-treatment displayed only minor alterations in taxa for which little metabolic information is available, a result which was mirrored previously in similarly designed trials of rifaximin in IBS $(140,141)$. Indeed, it must be reiterated that less than half of the IBD cohort studied in this trial were confirmed to have concomitant SIBO and the samples investigated (i.e., faeces) bears little resemblance to the site most relevant to the disease; therefore, no definitive conclusions on SIBO pathogenesis should be drawn from this data. 
With regards to SIBO in children, one study outlined above aimed to investigate the microbiota in sub-Saharan children with stunted growth (6). In addition to faecal microbiota analysis, it was deemed pertinent to retrieve and analyse the microbiota of small intestinal aspirates, due to its role in nutrient absorption and malnutrition. The authors declared a form of microbial "decompartmentalization," in which oropharyngealassociated microbes were found to be over-represented in the small intestine of these children, $91 \%$ of which tested positive for SIBO. Although this was deduced primarily from culture-based methods, it is consistent with preliminary reports suggesting that SIBO is not caused by migratory colonic microbes (142). In turn, $16 \mathrm{~S}$ rRNA sequencing of the duodenal microbiota in these subjects revealed a community containing near-equal parts Proteobacteria (32.4\%), Bacteroidetes (29.6\%), and Firmicutes (25.6\%), with lesser portions of Fusobacteria (9.2\%), and Actinobacteria (1.7\%). Critically, however, this study was severely limited by the fact that there are no appropriate controls available for the microbiota analysis of duodenal aspirates, presumably due to ethical considerations. Therefore, we are left, once again, with half-truths and a degree of speculation on the potential role and composition of the small intestinal microbiota in SIBO.

These studies demonstrate that SIBO has been regarded largely as a sign or sequela of a gastrointestinal disorder, rather than a discrete disorder in itself. This perspective has meant that the pathogenesis of SIBO has sparsely been addressed directly, but rather has been of peripheral interest in studies with an intersecting interest. Having said this, perhaps the most informative characterisation effort of SIBO to date has come from a recent investigation of 126 adults displaying gastrointestinal symptoms (66 SIBO positive and 60 SIBO negative) (143). The authors uncovered that, although duodenal aspirate culture results do not correlate with symptoms, the aspirate microbiome was significantly altered in symptomatic participants. This altered microbiome is characterised primarily by decreased levels of the genus Prevotella and enhanced microbial metabolism of ascorbic acid. In addition, it was identified that age, recent antibiotic exposure, PPI use and diet were the major proponents in the disruption of the microbiome and onset of symptoms. In line with this, the investigators demonstrated that a dietary fibre restriction intervention in healthy high-fibre consuming individuals had significant effects on the microbiome and triggered gastrointestinal symptoms common to SIBO. This study identifies several potentially targetable components of SIBO pathogenesis and represents an excellent blueprint for the future study of the disease.

\section{TREATMENT}

Due to the relative inaccessibility of duodenal samples for culture and difficulty in differentiating the culpable microorganism in a diverse ecosystem such as the small intestine, antibiotic therapy is generally initiated on an empiric basis. A 2013 systematic review and meta-analysis of antibiotic use in the context of SIBO found that rifaximin was by far the most commonly applied
(144). While the meta-analysis ruled in favour of antibiotic use over placebo (effectiveness ratio 2.55, CI 1.29-5.04), rifaximin failed to reach a significant superiority (effectiveness ratio 1.97, CI 0.93-4.17). However, just three studies were deemed appropriate for this analysis and their heterogeneity limit the usefulness of this result. In line with this, the systematic review went on to reveal that monotherapy with $1,200 \mathrm{mg} / \mathrm{d}$ rifaximin was efficacious, at $60.8 \%$ remission. Moreover, the antibiotic reached a substantially heightened efficacy of $85 \%$ when combined with partially hydrolysed guar gum, albeit in a single trial. Two studies included in the systematic review investigated the use of metronidazole, demonstrating a return to normal breath test in $51 \%$ of SIBO patients; while a single small study reported remission in all 14 patients recruited and treated with ciprofloxacin.

A more recent systematic review and meta-analysis of rifaximin therapy in SIBO included data from $>1,300$ patients (145). A dose-dependent response was demonstrated for eradication rates and, in line with the previous systematic review, the most commonly used dose was $1,200 \mathrm{mg} / \mathrm{d}$, with one study reporting $600 \mathrm{mg} / \mathrm{d}$ and another $1,600 \mathrm{mg} / \mathrm{d}$. The investigators found an overall eradication rate of $70 \%$, with adverse events reported in $<5 \%$. In addition, in a subset of studies which assessed symptom severity and resolution, meta-analysis revealed remission from symptomology in $68 \%$ of patients who were found to be successfully eradicated of SIBO. These studies demonstrate the efficacy and safety of rifaximin in the treatment of SIBO and its symptoms.

While the studies included in the above meta-analysis were all conducted with adult cohorts, one study previously investigated the use of rifaximin in children (48). Applying a regimen of $600 \mathrm{mg} / \mathrm{d}$ for 1 week, the investigators reported a rate of $64 \%(n=21 / 33)$ in breath test normalisation response. In light of the limited available data, a dose response study of rifaximin in a paediatric population would indeed be of interest. Finally, one study investigated the efficacy of a combination regimen of trimethoprim-sulfamethoxazole (TMP-SMT; $30 \mathrm{mg} \mathrm{kg}^{1} \mathrm{~d}^{1}$ ) and metronidazole (MTZ; $20 \mathrm{mg}$ $\mathrm{kg}^{1} \mathrm{~d}^{1}$ ) twice daily for 2 weeks in slum-dwelling children suffering from SIBO (146). When retested for SIBO by breath test 1 month after commencement of this therapy, the authors noted 95\% $(n=19 / 20)$ resolution of the disorder. However, the lack of a placebo or non-intervention control group limits assessment of temporal effects on SIBO status. Taken together, these results indicate that antibiotics are an effective means of treating SIBO in children and, although non-rifaximin antibiotics appear to produce greater resolution, the data is weaker for such medications and rifaximin has demonstrated safety in a greater number of participants and studies.

While antibiotics remain the first-line and gold-standard approach to SIBO management, there are additional or alternative approaches that may have application in the future, but the efficacy of which remains uncertain at present. For instance, there is biologic plausibility to the hypothesis that there may be a role for low FODMAP (Fermentable Oligosaccharides, Disaccharides, Monosaccharides, and Polyols) 
diets in decreasing fermentable substrates in the context of SIBO. Low FODMAP diets aim to greatly deplete or entirely eliminate the highly fermentable simple carbohydrates which are commonly found in certain dairy products, fruits, vegetables, nuts and legumes, with the ultimate aim of graded reintroduction of specific FODMAPs to elucidate the culpable source (147).

Interestingly, probiotics have also previously been considered as potential agents in the management of SIBO (148). In line with this, a more recent meta-analysis evaluating the efficacy of this avenue revealed that probiotic intervention resulted in vastly reduced $\mathrm{H}_{2}$ levels (WMD -36.35 , CI -44.23-28.47) and increased rates of decontamination (RR 3.29, CI 1.47-7.36) when compared to placebo. More intriguingly, however, is that probiotics also demonstrated more favourable results when compared directly to metronidazole treatment (RR 1.49, CI 1.07-2.08). Despite this, the best results overall were obtained when probiotics were combined with rifaximin or minocycline.

Finally, there is some evidence to suggest that certain statins may have a role in depleting Methanobrevibacter spp., thereby offering a novel therapy for methane-specific SIBO $(149,150)$. In line with this, a modified-release formulation of lovastatin, termed SYN-010, has been created to deliver the drug in a biphasic manner during transit, thereby avoiding considerable degradation and absorption in the upper gastrointestinal tract (151). A dose of $42 \mathrm{mg}$ /day of SYN-010 for as little as seven days was demonstrated to significantly reduce methane production when compared to placebo in a multi-centred double-blind RCT (152). Moreover, this promising therapy recently entered an efficacy and safety trial in patients with IBS (ClinicalTrials.gov ID: NCT03763175). The effect of this drug appears to be primarily due to the HMG-CoA reductase inhibition attributes of statins, thereby preventing the formation of mevalonate, a primary precursor in of key membrane lipids specific to archaea. This mechanism, along with several others, has been previously reviewed extensively elsewhere (41), and so, will not be discussed further herein.

\section{REFERENCES}

1. Miazga A, Osinski M, Cichy W, Zaba R. Current views on the etiopathogenesis, clinical manifestation, diagnostics, treatment and correlation with other nosological entities of SIBO. Adv Med Sci. (2015) 60:118-24. doi: 10.1016/j.advms.2014.09.001

2. Collins BS, Lin HC. Double-blind, placebo-controlled antibiotic treatment study of small intestinal bacterial overgrowth in children with chronic abdominal pain. J Pediatr Gastroenterol Nutr. (2011) 52:382-6. doi: 10.1097/MPG.0b013e3181effa3b

3. de Boissieu D, Chaussain M, Badoual J, Raymond J, Dupont C. Smallbowel bacterial overgrowth in children with chronic diarrhea, abdominal pain, or both. J Pediatr. (1996) 128:203-7. doi: 10.1016/S0022-3476(96)7 0390-6

4. Korterink JJ, Benninga MA, Van Wering HM, Deckers-Kocken JM. Glucose hydrogen breath test for small intestinal bacterial overgrowth in children with abdominal pain-related functional gastrointestinal disorders. J Pediatr Gastroenterol Nutr. (2015) 60:498-502. doi: 10.1097/MPG.0000000000000634

\section{PROGNOSIS}

At present, it is unclear whether the gut microbiota changes that characterise paediatric SIBO have detrimental effects in the longterm. In order to shed light on the long, and even short-term prognosis of children with SIBO, large scale, prospective studies are warranted.

\section{CONCLUSION}

Herein, we attempted to synthesise the most current literature on paediatric SIBO, from a gut microbiota perspective. Paediatric SIBO is a heterogenous and poorly understood entity, whose prevalence and incidence are difficult to determine due to the lack of uniformity and consensus of its diagnostic criteria. However, based upon the available literature, it appears that SIBO is a common underlying diagnosis in children who present clinically with certain FGDs and stunted growth, and in children with history of acid suppressive therapies, intestinal motility disturbances, anatomical alterations, or impoverished conditions. Further research with integration of culturedependant and culture-independent approaches is needed in order to (1) understand paediatric SIBO pathogenesis, clinical presentation, and prognosis, and (2) establish global consensus on the diagnostic criteria for SIBO.

\section{AUTHOR CONTRIBUTIONS}

DA contributed conception and design of the manuscript. DA and PR wrote the first draft of the manuscript. ET, JR, and EQ wrote and edited sections of the manuscript. All the authors contributed to manuscript revision, read, and approved the submitted version.

\section{ACKNOWLEDGMENTS}

We would like to thank Shelby Lee Avelar for her substantial contribution in the proofreading and editing of the manuscript.

5. Siniewicz-Luzenczyk K, Bik-Gawin A, Zeman K, Bak-Romaniszyn L. Small intestinal bacterial overgrowth syndrome in children. Gastroenterol Rev. (2015) 1:28-32. doi: 10.5114/pg.2014.47494

6. Vonaesch P, Morien E, Andrianonimiadana L, Sanke H, Mbecko JR, Huss KE. Stunted childhood growth is associated with decompartmentalization of the gastrointestinal tract and overgrowth of oropharyngeal taxa. Proc Natl Acad Sci USA. (2018) 36:E8489-98. doi: 10.1073/pnas.1806573115

7. Cares K, Al-Ansari N, Macha S, Zoubi N, Zaghloul H, Thomas R, et al. Risk of small intestinal bacterial overgrowth with chronic use of proton pump inhibitors in children. Eur J Gastroenterol Hepatol. (2017) 29:396-9. doi: 10.1097/MEG.0000000000000815

8. Rosen R, Amirault J, Liu H, Mitchell P, Hu L, Khatwa U, et al. Changes in gastric and lung microflora with acid suppression acid suppression and bacterial growth. JAMA Pediatr. (2015) 168:932-7. doi: 10.1001/jamapediatrics.2014.696

9. Hegar B, Hutapea EI, Advani N, Vandenplas Y. A double-blind placebocontrolled randomized trial on probiotics in small bowel bacterial overgrowth in children treated with omeprazole. J Pediatr. (2013) 89:381-7. doi: 10.1016/j.jped.2012.12.005 
10. Sieczkowska A, Landowski P, Zagozdzon P, Kaminska B, Lifschitz C. Small bowel bacterial overgrowth associated with persistence of\& abdominal symptoms in children treated with a proton pump inhibitor. J Pediatr. (2015) 166:1310-12.e1 doi: 10.1016/j.jpeds.2015.01.004

11. Lisowska A, Wójtowicz J, Walkowiak J. Small intestine bacterial overgrowth is frequent in cystic fibrosis : combined hydrogen and methane measurements are required for its detection. Acta Biochim Pol. (2009) 56:631-4. doi: 10.18388/abp.2009_2495

12. Fridge JL, Conrad C, Gerson L, Castillo RO, Cox K. Risk factors for small bowel bacterial overgrowth in cystic fibrosis. J Pediatr Gastroenterol Nutr. (2007) 44:212-8. doi: 10.1097/MPG.0b013e31802c0ceb

13. Lewindon PJ, Robb TA, Moore DJ, Davidson GP, Martin AJ. Bowel dysfunction in cystic fibrosis: Importance of breath testing. J Paediatr Child Health. (1998) 34:79-82. doi: 10.1046/j.1440-1754.1998.00159.x

14. Ojetti V, Bruno G, Paolucci V, Triarico S, D'aversa F, Ausili E, et al. The prevalence of small intestinal bacterial overgrowth and methane production in patients with myelomeningocele and constipation. Spinal Cord. (2014) 131:61-4. doi: 10.1038/sc.2013.131

15. Leiby A, Mehta D, Gopalareddy V, Jackson-walker S, Horvath K. Bacterial overgrowth and methane production in children with encopresis. J Pediatr. (2010) 156:766-70. doi: 10.1016/j.jpeds.2009.10.043

16. Cole CR, Frem JC, Schmotzer B, Gewirtz AT, Meddings JB, Gold BD, et al. The rate of bloodstream infection is high in infants with short bowel syndrome: relationship with small bowel bacterial overgrowth, enteral feeding, and inflammatory and immune responses. J Pediatr. (2010) 156:9417. doi: 10.1016/j.jpeds.2009.12.008

17. Gutierrez IM, Horng K, Calvert CE, Johnson VM, Zurakowski D, Kamin D, et al. Risk factors for small bowel bacterial overgrowth and diagnostic yield of duodenal aspirates in children with intestinal failure : a retrospective review. J Pediatr Surg. (2012) 47:1150-4. doi: 10.1016/j.jpedsurg.2012.03.019

18. Galloway D, Mezoff E, Zhang W, Byrd M, Cole C, Aban I, et al. Serum unconjugated bile acids and small bowel bacterial overgrowth in pediatric intestinal failure : a pilot study. J Parenter Enter Nutr. (2018) 43:263-70. doi: 10.1002/jpen.1316

19. Han SM, Jaksic T, Hong CR, Carey AN, Staffa SJ, Modi BP. Long-term outcomes of ultra-short bowel syndrome due to malrotation with midgut volvulus managed at an interdisciplinary pediatric intestinal rehabilitation center. J Pediatr Surg. (2019) 54:2017-20. doi: 10.1016/j.jpedsurg.2019.01.025

20. Fontenele-Soares AC, Lederman HM, Fagundes-Neto U, de Morais MB. Breath methane associated with slow colonic transit time in children with chronic constipation. J Clin Gastroenterol. (2005) 39:512-5. doi: 10.1097/01.mcg.0000165665.94777.bd

21. Pereira SP, Khin-Maung-U, Bolin TD, Ducombe VM, NyuntNyunt-Wai, Myo-Khin, et al. A pattern of breath hydrogen excretion suggesting small bowel bacterial overgrowth in burmese village children. J Pediatr Gastroenterol Nutr. (1991) 13:32-8. doi: 10.1097/00005176-199107000-00006

22. Dos Reis JC, De Morais MB, Oliva CAG, Fagundes-Neto U. Breath hydrogen test in the diagnosis of environmental enteropathy in children living in an urban slum. Dig Dis Sci. (2007) 52:1253-8. doi: 10.1007/s10620-006-9288-9

23. Mello CS, Tahan S, Melli LCF, Rodrigues MS do C, Mello RMP de, Scaletsky ICA, et al. Methane production and small intestinal bacterial overgrowth in children living in a slum. (2012) 18:5932-9. doi: 10.3748/wjg.v18.i41.5932

24. Mello CS, Rodrigues MS do C, Araújo HB de F, Melli LCFL, Tahan S, Pignatari ACC, et al. Fecal microbiota analysis of children with small intestinal bacterial overgrowth among residents of an urban slum in Brazil. $J$ Pediatr. (2017) 94:483-90 doi: 10.1016/j.jped.2017.09.003

25. Donowitz JR, Haque R, Kirkpatrick BD, Alam M, Lu M, Kabir $\mathrm{M}$, et al. Small intestine bacterial overgrowth and environmental enteropathy in Bangladeshi children. MBio. (2016) 7:e02102-15. doi: $10.1128 / \mathrm{mBio} .02102-15$

26. Gaffar SMA, Mahfuz M, Donowitz JR, Ahmed T. Impact of small intestine bacterial overgrowth on response to a nutritional intervention in bangladeshi children from an urban community. Am J Trop Med Hyg. (2018) 100:1-4. doi: 10.4269/ajtmh.18-0759

27. Ahlawat S, Baby R, Jabbour SK. Gastrointestinal anatomy In: Radiation Therapy for Gastrointestinal Cancers. Cham: Springer (2017). Available from: https://link.springer.com/chapter/10.1007\%2F978-3-319-43115-4_2\# citeas

28. Welcome MO. Gastrointestinal Physiology Development, Principles and Mechanisms of Regulation. Springer International Publishing (2018). Available online at: https://www.springer.com/la/book/9783319910550

29. Theis KR, Romero R, Winters AD, Greenberg JM, Gomez-Lopez N, Alhousseini A, et al. Does the human placenta delivered at term have a microbiota? Results of cultivation, quantitative real-time PCR, 16S rRNA gene sequencing, and metagenomics. Am J Obstet Gynecol. (2019) 220:267.e1-267.e39. doi: 10.1016/j.ajog.2018.10.018

30. Avelar Rodriguez D, Peña Vélez R, Toro Monjaraz EM, Ramirez Mayans J, Ryan PM. The gut microbiota: a clinically impactful factor in patient health and disease. SN Compr Clin Med. (2018) 1:188-99. doi: 10.1007/s42399-018-0036-1

31. Bohm M, Siwiec RM, Wo JM. Diagnosis and management of small intestinal bacterial overgrowth. Nutr Clin Pract. (2013) 28:289-99. doi: $10.1177 / 0884533613485882$

32. Donaldson GP, Lee SM, Mazmanian SK. Gut biogeography of the bacterial microbiota. Nat Rev Microbiol. (2015) 14:20-32. doi: 10.1038/nrmicro3552

33. Hillman ET, Lu H, Yao T, Nakatsu CH. Microbial ecology along the gastrointestinal tract. Microbes Environ Environ. (2017) 32:300-13. doi: 10.1264/jsme2.ME17017

34. Sender R, Fuchs S, Milo R. Revised estimates for the number of human and bacteria cells in the body. PLoS Biol. (2016) 14:1-14. doi: 10.1371/journal.pbio.1002533

35. Odamaki T, Kato K, Sugahara H, Hashikura N, Takahashi S, Xiao JZ, et al. Age-related changes in gut microbiota composition from newborn to centenarian: a cross-sectional study. BMC Microbiol. (2016) 16:1-12. doi: 10.1186/s12866-016-0708-5

36. Rinninella E, Universitario P, Gemelli A, Raoul P, Cintoni M, Mele MC. What is the healthy gut microbiota composition? a changing ecosystem what is the healthy gut microbiota composition? A changing ecosystem across age, environment, diet, and diseases. Microorganisms. (2019) 7:E14. doi: 10.3390/microorganisms7010014

37. Rizzatti G, Lopetuso LR, Gibiino G, Binda C, Gasbarrini A. Proteobacteria: a Common factor in human diseases. Biomed Res Int. (2017) 2017:1-7. doi: 10.1155/2017/9351507

38. Ross PR, Stanton C, Dalmasso M, McCann A, Ryan CA, Mills S, et al. Viromes of one year old infants reveal the impact of birth mode on microbiome diversity. PeerJ. (2018) 6:e4694. doi: 10.7717/peerj.4694

39. Knights D, Gale CA, Heisel T, Dominguez-Bello MG, Ward TL, Al-Ghalith G. Development of the human mycobiome over the first month of life and across body sites. mSystems. (2018) 3:1-12. doi: 10.1128/mSystems.00140-17

40. Gaci N, Borrel G, Tottey W, O'Toole PW, Brugère JF. Archaea and the human gut: new beginning of an old story. World J Gastroenterol. (2014) 20:16062-78. doi: 10.3748/wjg.v20.i43.16062

41. Gottlieb K, Wacher V, Sliman J, Pimentel M. Review article : inhibition of methanogenic archaea by statins as a targeted management strategy for constipation and related disorders. Aliment Pharmacol Ther. (2016) 43:197212. doi: 10.1111/apt.13469

42. Aidy SE, van den Bogert B, Kleerebezem M. The small intestine microbiota, nutritional modulation and relevance for health. Curr Opin Biotechnol. (2015) 32:14-20. doi: 10.1016/j.copbio.2014.09.005

43. Claesson MJ, Clooney AG, O'Toole PW. A clinician's guide to microbiome analysis. Nat Rev Gastroenterol Hepatol. (2017) 14:585-95. doi: $10.1038 /$ nrgastro. 2017.97

44. Pignata C, Budillon G, Monaco G, Nani E, Cuomo R, Parrilli G, et al. Jejunal bacterial overgrowth and intestinal permeability in children with immunodeficiency syndromes. Gut. (1990) 31:879-82. doi: 10.1136/gut.31.8.879

45. Scarpellini E, Giorgio V, Gabrielli M, Lauritano EC, Pantanella A, Fundarò $\mathrm{C}$, et al. Prevalence of small intestinal bacterial overgrowth in children with irritable bowel syndrome: a case-control study. J Pediatr. (2009) 155:416-20. doi: 10.1016/j.jpeds.2009.03.033

46. Collins BS, Lin HC. Chronic abdominal pain in children is associated with high prevalence of abnormal microbial fermentation. Dig Dis Sci. (2010) 55:124-30. doi: 10.1007/s10620-009-1026-7 
47. Jones HF, Davidson GP, Brooks DA, Butler RN. Is small-bowel bacterial overgrowth an underdiagnosed disorder in children with gastrointestinal symptoms? J Pediatr Gastroenterol Nutr. (2011) 52:632-4. doi: 10.1097/MPG.0b013e31820d5c16

48. Scarpellini E, Giorgio V, Gabrielli M, Filoni S, Vitale G, Tortora A, et al. Rifaximin treatment for small intestinal bacterial overgrowth in children with irritable bowel syndrome. Eur Rev Med Pharmacol Sci. (2013) 17:1314-20.

49. Lisowska A, Kobelska-dubiel N, Jankowska I, Pawłowska J, Moczko J, Walkowiak J. Small intestinal bacterial overgrowth in patients with progressive familial intrahepatic cholestasis. Acta Biochim Pol. (2014) 61:103-7. doi: 10.18388/abp.2014_1930

50. Wang L, Mei Y, You Y, Zhang J, Lu N, Liu N. Hydrogen breath test to detect small intestinal bacterial overgrowth: a prevalence case control study in autism. Eur Child Adolesc Psychiatry. (2018) 27:233-40. doi: 10.1007/s00787-017-1039-2

51. Belei O, Olariu L, Dobrescu A, Marcovici T, Marginean O. The relationship between non-alcoholic fatty liver disease and small intestinal bacterial overgrowth among overweight and obese children and adolescents. J Pediatr Endocrinol Metab. (2017) 30:1161-8. doi: 10.1515/jpem-2017-0252

52. Furnari1 M, Alessandri A De, Cresta F, Haupt M, Bassi M, Calvi A, et al. The role of small intestinal bacterial overgrowth in cystic fibrosis: a randomized case-controlled clinical trial with rifaximin. J Gastroenterol. (2018) 54:261-70 doi: 10.1007/s00535-018-1509-4

53. Prendergast AJ, Harper KM, Mutasa M, Manges AR, Humphrey J. Environmental enteric dysfunction pathways and child stunting: a systematic review. PLoS Negl Trop Dis. (2018) 12:e0006205. doi: 10.1371/journal.pntd.0006205

54. Polkowska-Pruszynska B, Gerkowicz A, Szczepanik-Kułak P, Krasowska D. Small intestinal bacterial overgrowth in systemic sclerosis: a review of the literature. Arch Dermatol Res. (2019) 311:1-8. doi: 10.1007/s00403-018-1874-0

55. Donowitz JR Petri WA Jr. Pediatric small intestine bacterial overgrowth in low-income countries. Trends Mol Med. (2014) 21:6-15. doi: 10.1016/j.molmed.2014.11.001

56. Batista M, Morais D, Alves G. Environmental enteric dysfunction and growth? J Pediatr (Rio J) (2018) 95:85-94. doi: 10.1016/j.jped.2018.11.004

57. Rogawski ET, Guerrant RL. The burden of enteropathy and "Subclinical" infections. Pediatr Clin NA. (2017) 64:815-36. doi: 10.1016/j.pcl.2017.03.003

58. Bures J, Cyrany J, Kohoutova D, Förstl M, Rejchrt S, Kvetina J, et al. Small intestinal bacterial overgrowth syndrome. World J Gastroenterol. (2010) 16:2978-90. doi: 10.3748/wjg.v16.i24.2978

59. Adike A, DiBaise JK. Small intestinal bacterial over growth. Gastroenterol Clin NA. (2017) 3:112-22

60. Guerrant RL, Leite AM, Pinkerton R, Medeiros PHQS, Cavalcante PA, DeBoer $\mathrm{M}$, et al. Biomarkers of environmental enteropathy, inflammation, stunting, and impaired growth in children in northeast Brazil. PLoS ONE. (2016) 11:1-20. doi: 10.1371/journal.pone.0158772

61. Ghoshal UC, Srivastava D. Irritable bowel syndrome and small intestinal bacterial overgrowth: meaningful association or unnecessary hype. World J Gastroenterol. (2014) 20:2482-91. doi: 10.3748/wjg.v20.i10.2482

62. Paul J. Lappinga, Abraham SC, Murray JA, Emily A. Vetter B, Patel R, Wu TT. Histopathologic Features and Clinical Correlates in an Underrecognized Entity. Arch Pathol Lab Med. (2010) 134:264-70.

63. Kerac M, Voskuijl W, Priebe MG, Kvissberg MA, Bandsma RHJ, Berkley JA, et al. Carbohydrate malabsorption in acutely malnourished children and infants: a systematic review. Nutr Rev. (2015) 74:48-58. doi: 10.1093/nutrit/nuv058

64. Zhao J, Fox M, Cong Y, Chu H, Shang Y, Fried M, et al. Lactose intolerance in patients with chronic functional diarrhoea: the role of small intestinal bacterial overgrowth. Aliment Pharmacol Ther. (2010) 31:892-900. doi: 10.1111/j.1365-2036.2010.04252.x

65. Canani RB, Costanzo M Di, Leone L, Pedata M, Meli R, Calignano A. Potential beneficial effects of butyrate in intestinal and extraintestinal diseases. World J Gastroenterol. (2011) 17:1519-28. doi: 10.3748/wjg.v17.i12.1519

66. Campbell DI, Elia M, Lunn PG. Growth faltering in rural gambian infants is associated with impaired small intestinal barrier function, leading to endotoxemia and systemic inflammation. J Nutr. (2018) 133:1332-8. doi: $10.1093 / \mathrm{jn} / 133.5 .1332$

67. Turvey SE, Broide DH. Innate immunity. J Allergy Clin Immunol. (2010) 125:S24-32. doi: 10.1016/j.jaci.2009.07.016

68. Martinsen TC, Bergh K, Waldum HL. Gastric juice: a barrier against infectious diseases. Basic Clin Pharmacol Toxicol. (2005) 96:94-102. doi: 10.1111/j.1742-7843.2005.pto960202.x

69. Cohen S, Mesquita MB de, Mimouni FB. Adverse effects reported in the use of gastroesophageal reflux disease treatments in children: a 10 years literature review. Br J Clin Pharmacol. (2015) 80:200-2008. doi: 10.1111/bcp.12619

70. Ward RM, Kearns GL. Proton pump inhibitors in pediatrics : mechanism of action, pharmacokinetics, pharmacogenetics, and pharmacodynamics. Pediatr Drugs. (2013) 15:119-31. doi: 10.1007/s40272-013-0012-x

71. Canani RB, Cirillo P, Roggero P, Romano C, Malamisura B, Terrin G, et al. Therapy with gastric acidity inhibitors increases the risk of acute gastroenteritis and community-acquired pneumonia in children. Pediatrics. (2006) 117:e817 LP-e820. doi: 10.1542/peds.2005-1655

72. Benninga MA, Nurko S, Faure C, Hyman PE, St. James Roberts I, Schechter NL. Childhood functional gastrointestinal disorders: neonate/toddler. Gastroenterology. (2016) 150:1443-55e2. doi: 10.1053/j.gastro.2016.02.016

73. Rosen R. Gastroesophageal reflux in infants: more than just a pHenomenon. JAMA Pediatr. (2014) 168:83-9. doi: 10.1001/jamapediatrics.2013.2911

74. Rosen R, Vandenplas Y, Singendonk M, Cabana M, Di Lorenzo C, Staiano $\mathrm{A}$, et al. Pediatric gastroesophageal reflux clinical practice guidelines: joint recommendations of the north American society for pediatric gastroenterology, hepatology, and nutrition (NASPGHAN) and the European Society for pediatric gastroenterology, hepatology, and nutrition. J Pediatr Gastroenterol Nutr. (2018) 66:516-54. doi: 10.1097/MPG.0000000000001889

75. Jimenez J, Drees M, Loveridge-Lenza B, Eppes S, DelRosario F. Exposure to gastric acid-suppression therapy is associated with health care- and community-associated clostridium difficile infection in children. J Pediatr Gastroenterol Nutr. (2015) 61:208-11. doi: 10.1097/MPG.0000000000000790

76. Freedberg DE, Lamousé-Smith ES, Lightdale JR, Jin Z, Yang YX, Abrams JA. Use of acid suppression medication is associated with risk for C. difficile infection in infants and children: a population-based study. Clin Infect Dis. (2015) 61:912-7. doi: 10.1093/cid/civ432

77. Wei L, Ratnayake L, Phillips G, McGuigan CC, Morant SV, Flynn RW, et al. Acid-suppression medications and bacterial gastroenteritis: a population-based cohort study. Br J Clin Pharmacol. (2017) 83:1298-308. doi: 10.1111/bcp.13205

78. Castellani C, Singer G, Kashofer K, Huber-zeyringer A, Flucher C, Kaiser $\mathrm{M}$, et al. The influence of proton pump inhibitors on the fecal microbiome of infants with gastroesophageal reflux - a prospective longitudinal interventional study. (2017) 7:1-7. doi: 10.3389/fcimb.2017.00444

79. Imhann F, Bonder MJ, Vila AV, Fu J, Mujagic Z, Vork L, et al. Proton pump inhibitors affect the gut microbiome. Gut. (2016) 65:740-8. doi: 10.1136/gutjnl-2015-310376

80. Sieczkowska A, Landowski P, Zagozdzon P, Kaminska B, Lifschitz C. The association of proton pump inhibitor therapy and small bowel bacterial overgrowth in children. Eur J Gastroenterol Hepatol. (2017) 29:1190-1. doi: 10.1097/MEG.0000000000000946

81. Su T, Lai S, Lee A, He X, Chen S. Meta-analysis: proton pump inhibitors moderately increase the risk of small intestinal bacterial overgrowth. $J$ Gastroenterol. (2018) 53:27-36. doi: 10.1007/s00535-017-1371-9

82. Lo WK, Chan WW. Proton pump inhibitor use and the risk of small intestinal bacterial overgrowth: a meta-analysis. Clin Gastroenterol Hepatol. (2013) 11:483-90. doi: 10.1016/j.cgh.2012.12.011

83. Deloose E, Janssen P, Depoortere I, Tack J. The migrating motor complex: control mechanisms and its role in health and disease. Nat Rev Gastroenterol Hepatol. (2012) 9:271-85. doi: 10.1038/nrgastro.2012.57

84. Deloose E, Tack J. Redefining the functional roles of the gastrointestinal migrating motor complex and motilin in small bacterial overgrowth and hunger signaling. Am J Physiol Liver Physiol. (2015) 310:G228-33. doi: 10.1152/ajpgi.00212.2015

85. Li SC. Scleroderma in children and adolescents: localized scleroderma and systemic sclerosis. Pediatr Clin North Am. (2018) 65:757-81. doi: $10.1016 /$ j.pcl.2018.04.002 
86. Dorsey J, Gonska T. Bacterial overgrowth, dysbiosis, inflammation, and dysmotility in the cystic fibrosis intestine. J Cyst Fibros. (2017) 16:S14-23. doi: 10.1016/j.jcf.2017.07.014

87. Norkina O, Burnett TG, De Lisle RC. Bacterial overgrowth in the cystic fibrosis transmembrane conductance regulator null mouse small intestine. Infect Immun. 72:6040-9. doi: 10.1128/IAI.72.10.60406049.2004

88. De Lisle RC. Altered transit and bacterial overgrowth in the cystic fibrosis mouse small intestine. Am J Physiol Liver Physiol. (2007) 293:G104-11. doi: 10.1152/ajpgi.00548.2006

89. De Lisle RC, Roach E, Jansson K. Effects of laxative and N -acetylcysteine on mucus accumulation, bacterial load, transit, and inflammation in the cystic fibrosis mouse small intestine. Am J Physiol Liver Physiol. (2007) 293:G577-84. doi: 10.1152/ajpgi.00195.2007

90. Revaiah PC, Kochhar R, Rana S V, Berry N, Ashat M, Dhaka N, et al. Risk of small intestinal bacterial overgrowth in patients receiving proton pump inhibitors versus proton pump inhibitors plus prokinetics. JGH Open. (2018) 2:47-53. doi: 10.1002/jgh3.12045

91. Sarosiek I, Bashashati M, Alvarez A, Hall M, Shankar N, Gomez Y, et al. Lubiprostone accelerates intestinal transit and alleviates small intestinal bacterial overgrowth in patients with chronic constipation. Am J Med Sci. (2016) 352:231-8. doi: 10.1016/j.amjms.2016.05.012

92. Rezaie A, Buresi M, Lembo A, Lin H, McCallum R, Rao S, et al. Hydrogen and methane-based breath testing in gastrointestinal disorders: the North American consensus. Am J Gastroenterol. (2017) 112:775-84. doi: 10.1038/ajg.2017.46

93. Duggan CP, Jaksic T. Intestinal failure Jaksic. N Engl J Med. (2017) 377:66675. doi: 10.1056/NEJMra1602650

94. Piper HG. Intestinal microbiota in short bowel syndrome. Semin Pediatr Surg. (2018) 27:223-8. doi: 10.1053/j.sempedsurg.2018.07.007

95. Lilja HE, Wefer H, Nyström N, Finkel Y, Engstrand L. Intestinal dysbiosis in children with short bowel syndrome is associated with impaired outcome. Microbiome. (2015) 3:1-6. doi: 10.1186/s40168-015-0084-7

96. Chander Roland B, Mullin GE, Passi M, Zheng X, Salem A, Yolken R, et al. A prospective evaluation of ileocecal valve dysfunction and intestinal motility derangements in small intestinal bacterial overgrowth. Dig Dis Sci. (2017) 62:3525-35. doi: 10.1007/s10620-017-4726-4

97. Khin-Maung-U, Myo-Khin, Nyunt-Nyunt-Wai, Linklater JM, Pereira $\mathrm{SP}$, Bolin TD, et al. Absorption of carbohydrate from rice in Burmese village children and adults. Am J Clin Nutr. (1990) 52:342-7. doi: 10.1093/ajcn/52.2.342

98. Islam MM, Ahmed AS, Hossain MI, Ahmed T, Haque R, Gaffar SA, et al. The MAL-ED cohort study in Mirpur, Bangladesh. Clin Infect Dis. (2014) 59(suppl_4):S280-6. doi: 10.1093/cid/ciu458

99. Ghoshal UC, Goel A, Ghoshal U, Jain M, Misra A, Choudhuri G. Chronic diarrhea and malabsorption due to hypogammaglobulinemia: a report on twelve patients. Indian J Gastroenterol. (2011) 30:170. doi: 10.1007/s12664-011-0111-y

100. Losurdo G, Marra A, Shahini E, Girardi B, Giorgio F, Amoruso A, et al. Small intestinal bacterial overgrowth and celiac disease: a systematic review with pooled-data analysis. Neurogastroenterol Motil. (2017) 29:1-10. doi: $10.1111 /$ nmo. 13028

101. Sánchez E, Donat E, Ribes-Koninckx C, Fernández-Murga ML, Sanz Y. Duodenal-mucosal bacteria associated with celiac disease in children. Appl Environ Microbiol. (2013) 79:5472-9. doi: 10.1128/AEM.00869-13

102. Fernández-Crehuet FG, Tapia-Paniagua S, Gutiérrez MAM, NavasLópez VM, Serrano MJ, Blasco-Alonso J, et al. La composición de la microbiota duodenal en ninos con enfermedad celíaca activa está influenciada por el grado de enteropatía. An Pediatr. (2016) 84:224-30. doi: 10.1016/j.anpedi.2015.06.014

103. Pistiki A, Galani I, Pyleris E, Barbatzas C, Pimentel M, GiamarellosBourboulis EJ. In vitro activity of rifaximin against isolates from patients with small intestinal bacterial overgrowth. Int J Antimicrob Agents. (2014) 43:236-41. doi: 10.1016/j.ijantimicag.2013.12.008

104. Pyleris E, Giamarellos-Bourboulis JE, Tzivras D, Koussoulas V, Barbatzas C, et al. The prevalence of overgrowth by aerobic bacteria in the small intestine by small bowel culture : relationship with irritable bowel syndrome. Dig Dis Sci. (2012) 57:1321-9. doi: 10.1007/s10620-012-2033-7
105. Ghoshal UC, Baba CS, Ghoshal U, Alexander G, Misra A, Saraswat VA, et al. Low-grade small intestinal bacterial overgrowth is common in patients with non-alcoholic steatohepatitis on quantitative jejunal aspirate culture. Indian J Gastroenterol. (2017) 36:390-9. doi: 10.1007/s12664-017-0797-6

106. Thursby E, Juge N. Introduction to the human gut microbiota. Biochem J. (2017) 474:1823-36. doi: 10.1042/BCJ20160510

107. Young VB. The role of the microbiome in human health and disease: an introduction for clinicians. BMJ. (2017) 356:831. doi: 10.1136/bmj.j831

108. Morgan XC, Huttenhower C. Meta'omic analytic techniques for studying the intestinal microbiome. Gastroenterology. (2014) 146:1437-48.e1. doi: 10.1053/j.gastro.2014.01.049

109. Sieczkowska A, Landowski ÃP, Kaminska B, Lifschitz C. Small bowel bacterial overgrowth in children. J Pediatr Gastroenterol Nutr. (2016) 62:196207. doi: 10.1097/MPG.0000000000000920

110. Zhang Y, Du L, Dai N, Kim JJ-W, Chen B. Prevalence and predictors of small intestinal bacterial overgrowth in irritable bowel syndrome: a systematic review and meta-analysis. J Gastroenterol. (2018) 53:807-18. doi: 10.1007/s00535-018-1476-9

111. Menees S, Chey W. The gut microbiome and irritable bowel syndrome [version 1; referees: 3 approved]. F1000Prime Rep. (2018) 7:1-10. doi: 10.12688/f1000research.14592.1

112. Rodiño-Janeiro BK, Vicario M, Alonso-Cotoner C, Pascua-García R, Santos J. A review of microbiota and irritable bowel syndrome: future in therapies. Adv Ther. (2018) 35:289-310. doi: 10.1007/s12325-018-0673-5

113. Aziz I, Törnblom H, Simrén M. Small intestinal bacterial overgrowth as a cause for irritable bowel syndrome: guilty or not guilty? Curr Opin Gastroenterol. (2017) 33:196-202. doi: 10.1097/MOG.0000000000000348

114. Suri J, Kataria R, Malik Z, Parkman HP, Schey R. Elevated methane levels in small intestinal bacterial overgrowth suggests delayed small bowel and colonic transit. Medicine. (2018) 97:e10554. doi: 10.1097/MD.0000000000010554

115. Kunkel D, Basseri RJ, Makhani MD, Chong K, Chang C, Pimentel M. Methane on breath testing is associated with constipation: a systematic review and meta-analysis. Dig Dis. (2011) 56:1612-8. doi: 10.1007/s10620-011-1590-5

116. Pimentel M, Lin HC, Enayati P, Burg B Van Den, Lee H, Chen JH, et al. Methane, a gas produced by enteric bacteria, slows intestinal transit and augments small intestinal contractile activity. Am J Physiol Liver Physiol. (2006) 290:1089-95. doi: 10.1152/ajpgi.00574.2004

117. Ghoshal UC, Srivastava D, Misra A. A randomized double-blind placebocontrolled trial showing rifaximin to improve constipation by reducing methane production and accelerating colon transit : a pilot study. Indian J Gastroenterol. (2018) 37:416-23. doi: 10.1007/s12664-018-0901-6

118. The World Bank. Prevalence of Stunting, Height for Age (\% of Children Under 5). (2017). Available online at: https://data.worldbank.org/indicator/ SH.STA.STNT.ZS? end=2017\&locations=XN\&most_recent_year_desc= true\&start $=1983 \&$ view $=$ chart (accessed August 26, 2019).

119. Sarker SA, Ahmed T, Brussow H. Hunger and microbiology: is a low gastric acid-induced bacterial overgrowth in the small intestine a contributor to malnutrition in developing countries? Microb Biotechnol. (2017) 10:1025-30. doi: 10.1111/1751-7915.12780

120. Watanabe K, Petri WA. Environmental enteropathy: elusive but significant subclinical abnormalities in developing countries. EBioMedicine. (2016) 10:25-32. doi: 10.1016/j.ebiom.2016.07.030

121. Higham SE, Ahmad A, Sanders DS, Bird N, Elphick DA, Chew TS. Small bowel bacterial overgrowth in symptomatic older people: can it be diagnosed earlier? Gerontology. (2005) 51:396-401. doi: 10.1159/000088704

122. Parlesak A, Klein B, Schecher K, Bode JC, Bode C. Prevalence of small bowel bacterial overgrowth and its association with nutrition intake in nonhospitalized older adults. J Am Geriatr Soc. (2003) 51:768-73. doi: 10.1046/j.1365-2389.2003.51259.x

123. Walther B, Karl JP, Booth SL, Boyaval P. Menaquinones, bacteria, and the food supply: the relevance of dairy and fermented food products to vitamin K requirements. Adv Nutr. (2013) 4:463-73. doi: 10.3945/an.113.003855

124. Oliveira RB, Martinelli ALC, Troncon LEA, Elias J. Small intestinal bacterial overgrowth (SIBO) and Vitamin K-responsive coagulopathy: a previously unrecorded association. BMJ Case Rep. (2018) 2018:2017-9. doi: 10.1136/bcr-2017-223531 
125. Lamichhane S, Sen P, Dickens AM, Orešič M, Bertram HC. Gut metabolome meets microbiome: a methodological perspective to understand the relationship between host and microbe. Methods. (2018) 149:3-12. doi: 10.1016/j.ymeth.2018.04.029

126. Sundin OH, Mendoza-Ladd A, Morales E, Fagan BM, Zeng M, DiazArévalo D, et al. Does a glucose-based hydrogen and methane breath test detect bacterial overgrowth in the jejunum? Neurogastroenterol Motil. (2018) 30:e13350. doi: 10.1111/nmo.13350

127. Quigley EMM. The spectrum of small intestinal bacterial overgrowth (SIBO). Curr Gastroenterol Rep. (2019) 21:3. doi: 10.1007/s11894-019-0671-z

128. Pimentel M. Breath testing for small intestinal bacterial overgrowth: should we bother? Am J Gastroenterol. (2016) 111:307-8. doi: 10.1038/ajg.2016.30

129. Ghoshal UC. How to interpret hydrogen breath tests. J Neurogastroenterol Motil. (2011) 17:312-7. doi: 10.5056/jnm.2011.17.3.312

130. Gasbarrini A, Corazza GR, Gasbarrini G, Montalto M, Di Stefano M, Basilisco G, et al. Methodology and indications of H2breath testing in gastrointestinal diseases: The Rome consensus conference. Aliment Pharmacol Ther. (2009) 29(SUPPL. 1):1-3. doi: 10.1111/j.1365-2036.2009.03951.x

131. Smith NW, Shorten PR, Altermann EH, Roy NC, Warren C, Smith NW. Hydrogen cross-feeders of the human gastrointestinal tract Hydrogen crossfeeders of the human gastrointestinal tract. Gut Microbes. (2018) 10:1-19. doi: 10.1080/19490976.2018.1546522

132. Carbonero F, Benefiel AC, Gaskins HR. Contributions of the microbial hydrogen economy to colonic homeostasis. Nat Publ Gr. (2012) 9:504-18. doi: 10.1038/nrgastro.2012.85

133. Makki K, Deehan EC, Walter J, Bäckhed F. The impact of dietary fiber on gut microbiota in host health and disease. Cell Host Microbe. (2018) 23:705-15. doi: 10.1016/j.chom.2018.05.012

134. Wolf PG, Biswas A, Morales SE, Greening C, Wolf PG, Biswas A, et al. H 2 metabolism is widespread and diverse among human colonic microbes. Gut Microbes. (2016) 7:235-45. doi: 10.1080/19490976.2016.1182288

135. Maharaj AR, Edginton AN. Examining small intestinal transit time as a function of age - is there evidence to support age-dependent differences among children? Drug Metab Dispos. (2016) 44:1080-9. doi: $10.1124 / \mathrm{dmd} .115 .068700$

136. Khoshini R, Dai S-C, Lezcano S, Pimentel M. A systematic review of diagnostic tests for small intestinal bacterial overgrowth. Dig Dis Sci. (2008) 53:1443-54. doi: 10.1007/s10620-007-0065-1

137. Saad RJ, Chey WD. Breath testing for small intestinal bacterial overgrowth: maximizing test accuracy. Clin Gastroenterol Hepatol. (2014) 12:1964-72. doi: 10.1016/j.cgh.2013.09.055

138. Ghoshal U, Ghoshal UC, Ranjan P, Naik R. SR, Ayyagari A. Spectrum and antibiotic sensitivity of bacteria contaminating the upper gut in patients with malabsorption syndrome from the tropics. BMC Gastroenterol. (2003) 3:2-7. doi: 10.1186/1471-230X-3-9

139. Zhuang X, Tian Z, Li L, Zeng Z, Chen M, Xiong L. Fecal microbiota alterations associated with diarrhea-predominant irritable bowel syndrome. Front Microbiol. (2018) 9:1-11. doi: 10.3389/fmicb.2018.01600

140. Soldi S, Vasileiadis S, Uggeri F, Campanale M, Morelli L, Fogli MV, et al. Modulation of the gut microbiota composition by rifaximin in nonconstipated irritable bowel syndrome patients: a molecular approach. Clin Exp Gastroenterol. (2015) 8:309-25. doi: 10.2147/CEG.S89999

141. Acosta A, Camilleri M, Shin A, Linker Nord S, O’Neill J, Gray A V, et al. Effects of rifaximin on transit, permeability, fecal microbiome and organic acid excretion in irritable bowel syndrome. Clin Transl Gastroenterol. (2016) 7:e173. doi: 10.1038/ctg.2016.32
142. McCallum RW, Mendoza-ladd A, Zeng M, Diaz-Arevalo D, Morales E, Fagan BM, et al. Jejunal flora of patients with small intestinal bacterial overgrowth: dna sequencing provides no evidence for a migration of colonic microbes. Gastroenterology. (2017) 152:S629. doi: 10.1016/S0016-5085(17)3 2231-X

143. Saffouri GB, Shields-Cutler RR, Chen J, Yang Y, Lekatz HR, Hale VL, et al. Small intestinal microbial dysbiosis underlies symptoms associated with functional gastrointestinal disorders. Nat Commun. (2019) 10:2012. doi: 10.1038/s41467-019-09964-7

144. Shah SC, Day LW, Somsouk M, Sewell JL. Meta-analysis: Antibiotic therapy for small intestinal bacterial overgrowth. Aliment Pharmacol Ther. (2013) 38:925-34. doi: 10.1111/apt.12479

145. Gatta L, Scarpignato C, McCallum RW, Lombardo L, Pimentel M, D’Incà $\mathrm{R}$, et al. Systematic review with meta-analysis: rifaximin is effective and safe for the treatment of small intestine bacterial overgrowth. Aliment Pharmacol Ther. (2017) 45:604-16. doi: 10.1111/apt.13928

146. Tahan S, Melli LCFL, Mello CS, Rodrigues MSC, Filho HB, Morais MB de. Effectiveness of trimethoprim-sulfamethoxazole and metronidazole in the treatment of small intestinal bacterial overgrowth in children living in a slum. J Pediatr Gastroenterol Nutr. (2013) 57:316-8. doi: 10.1097/MPG.0b013e3182952e93

147. Staudacher HM, Irving PM, Lomer MCE, Whelan K. Mechanisms and efficacy of dietary FODMAP restriction in IBS. Nat Rev Gastroenterol Hepatol. (2014) 11:256-66. doi: 10.1038/nrgastro.2013.259

148. Quigley EMM, Quera R. Small intestinal bacterial overgrowth: roles of antibiotics, prebiotics, and probiotics. Gastroenterology. (2006) 130 (2 Suppl.):78-90. doi: 10.1053/j.gastro.2005.11.046

149. Wolin MJ, Miller TL. Control of rumen methanogenesis by inhibiting the growth and activity of methanogens with hydroxymethylglutaryl-SCoA inhibitors. Int Congr Ser. (2006) 1293:131-7. doi: 10.1016/j.ics.2006.01.031

150. Wacher V, Pimentel M, Kokai-Kun J, Sliman J, Muskal SM, Gottlieb K. Lovastatin lactone may improve irritable bowel syndrome with constipation (IBS-C) by inhibiting enzymes in the archaeal methanogenesis pathway. F1000Res. (2016) 5:606. doi: 10.12688/f1000research.8406.1

151. Hubert S, Chadwick A, Wacher V, Coughlin O, Kokai-Kun J, Bristol A. Development of a modified-release formulation of lovastatin targeted to intestinal methanogens implicated in irritable bowel syndrome with constipation. J Pharm Sci. (2018) 107:662-71. doi: 10.1016/j.xphs.2017.09.028

152. Gottlieb K, Wacher V, Sliman J, Coughlin O, McFall H, Rezaie A, et al. Su1210 SYN-010, a proprietary modified-release formulation of lovastatin lactone, lowered breath methane and improved stool frequency in patients with IBS-C: results of a multi-center randomized doubleblind placebo-controlled phase 2a trial. Gastroenterology. (2016) 150:S496-7. doi: 10.1016/S0016-5085(16)31709-7

Conflict of Interest Statement: The authors declare that the research was conducted in the absence of any commercial or financial relationships that could be construed as a potential conflict of interest.

Copyright (C) 2019 Avelar Rodriguez, Ryan, Toro Monjaraz, Ramirez Mayans and Quigley. This is an open-access article distributed under the terms of the Creative Commons Attribution License (CC BY). The use, distribution or reproduction in other forums is permitted, provided the original author(s) and the copyright owner(s) are credited and that the original publication in this journal is cited, in accordance with accepted academic practice. No use, distribution or reproduction is permitted which does not comply with these terms. 